NBER WORKING PAPER SERIES

\title{
THE LONG-TERM EFFECTS OF A GENEROUS INCOME SUPPORT PROGRAM: UNEMPLOYMENT INSURANCE IN NEW BRUNSWICK AND MAINE, 1940-1991
}

\author{
Peter Kuhn \\ Chris Riddell \\ Working Paper 11932 \\ http://www.nber.org/papers/w11932
NATIONAL BUREAU OF ECONOMIC RESEARCH 1050 Massachusetts Avenue
Cambridge, MA 02138
January 2006

This research was funded by the Canadian Studies Faculty Research Grant Program of the Canadian Embassy in Washington, D.C. We thank seminar participants at the University of British Columbia, University of Toronto, Queen's University, The Institute for the Study of Labor (IZA), the 2004 European Economics Association meetings, Madrid; 2004 European Association of Labour Economists meetings, Lisbon; and the 2005 IAB Conference on the Evaluation of Labour Market Programs, Nuremburg. We thank Matt Rice for assistance with maps and Elizabeth Beatty and Dong Hun Cho for research assistance. The views expressed herein are those of the author(s) and do not necessarily reflect the views of the National Bureau of Economic Research.

(O2006 by Peter Kuhn and Chris Riddell. All rights reserved. Short sections of text, not to exceed two paragraphs, may be quoted without explicit permission provided that full credit, including $\odot$ notice, is given to the source. 
The Long-Term Effects of a Generous Income Support Program: Unemployment Insurance in New Brunswick and Maine, 1940-1991

Peter Kuhn and Chris Riddell

NBER Working Paper No. 11932

January 2006

JEL No. J22, J64

\begin{abstract}
$\underline{\text { ABSTRACT }}$
Using data spanning a half century for adjacent jurisdictions in the U.S. and Canada, we study the long-term effects of a very generous unemployment insurance (UI)program on weeks worked. We find large effects. For example, in 1990, about 6 percent of employed men in Maine's northernmost counties worked fewer than 26 weeks per year; just across the border in New Brunswick that figure was over 20 percent. According to our estimates, New Brunswick's much more generous UI system accounts for about two thirds of this differential. Even greater effects are found among women and less-educated men. We argue that our longer-run, crossnational perspective generates more substantial estimates of program effects because it captures workers' abilities to make a wider variety of adjustments to programs they expect to be permanent.

Peter Kuhn

Department of Economics

UC, Santa Barbara

2127 North Hall

Santa Barbara, CA 93106

and NBER

pjkuhn@econ.ucsb.edu

Chris Riddell

School of Policy Studies

Queen's University

138 Union Street, Room 217

Kingston, Ontario K7L 3N6

Canada

riddellc@post.queensu.ca
\end{abstract}


"The members of our association are absolutely convinced that many persons voluntarily make what amounts to a way of life out of working only long enough to establish benefits, then drawing them for the maximum period, and then repeating the cycle." (Canadian Construction Labor Relations Association)

"UI...has created a dependency. People say 'I am going to get a job... and work 10 or 20 weeks or whatever I need for UI'. I find in lot of people that that seems to become a mentality where they continually think that way." (New Brunswick Association of Métis)

"The point we were trying to make, Mr. Chairman, is that many people deliberately choose to have seasonal employment and don't wish to work the rest of the year." (Canadian Electrical Distributors Association)

(All quotes taken from the Commission of Inquiry on Unemployment Insurance, 1986)

\section{Introduction}

Most existing studies of the labor market effects of income support programs share the following features: they focus on short-term responses to relatively small changes in a single program parameter, in a restricted subpopulation of workers. For example, a typical research paper on the incentive effects of unemployment insurance (UI) might examine the effects of the benefit replacement rate on unemployment durations using historical state-by-year variation in replacement rates for a sample of persons who have entered a spell of unemployment. ${ }_{\text {To avoid }}$ confounding the effects of these (typically small) policy changes with business cycles and other factors, attention is generally restricted to measuring effects that occur within a year or less of the implementation of a policy change. Studies of other income support programs share similar features. For example, a welfare study might measure the effects of the benefit level on length of claim for a sample of single mothers.

For the most part, the above limitations are not only unavoidable, but desirable: tightlydefined situations such as these are likely to yield the most precise estimates of policy effects. However, these limitations have led a number of critics (e.g. Murray 1994) to argue that existing

\footnotetext{
${ }^{1}$ See Krueger and Meyer (2002) for an up-to-date literature review on unemployment insurance and labor supply.
} 
econometric studies may understate the long-term work incentives of generous income support programs. According to such arguments, individuals may be poorly informed about small policy changes - the incentives to acquire this information are relatively low - and may (rationally) choose not to make large behavioral adjustments if they expect program changes to be temporary. Over a longer time horizon, individuals eligible for generous programs that they expect to be permanent may make larger behavioral adjustments, adjust on a wider number of margins, and build a 'lifestyle' around the program. Such effects tend not to be captured by studies focusing on short-term responses to modest changes in a single program parameter.

In this paper we take a different approach. Our goal is to estimate the long-term labor supply effects of large-scale changes in the overall generosity of an income support program for the entire population of workers in a region. Specifically, we exploit a dramatic natural experiment resulting from a national border - between the Canadian province of New Brunswick and the U.S. state of Maine - that divides a relatively homogeneous region. This strategy allows us to examine the effects of much larger policy changes. For example, in 1940, Maine had a modest UI system, but New Brunswick had none. By 1950, the two regions had quite similar UI systems. Since then, New Brunswick's system experienced two major expansions, and is currently much more generous than Maine's. By 1980, for example, 10 weeks worked per year in New Brunswick yielded, on average, an annual income (including UI benefits) equivalent to 33 weeks worth of earnings (in Maine, only 13 weeks). This could be done year after year, without penalty. Using the five decennial censuses spanning the period 1940-1991, we use this dramatic policy divergence to estimate the long-term effects of UI program generosity on labor supply.

\footnotetext{
${ }^{2}$ In regards to negative income tax experiments, Murray states: "Presumably people are less likely to burn bridges behind them if they know that the guaranteed income ends in three years than if it is legislated for life" (p.153).
} 
Our focus in this paper is on annual weeks worked by workers (i.e., by persons who work at

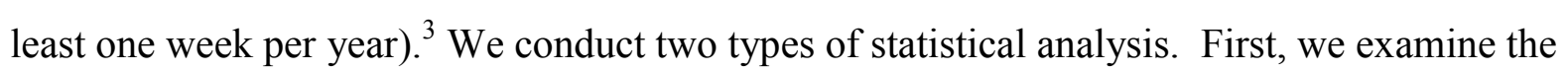
incidence of part-year work (defined as less than 40 weeks per year) using cell mean data for the 1940-91 Census years. For this analysis, the entire state of Maine serves as a "control group" for New Brunswick. Second, we estimate a more disaggregated distribution of annual work weeks

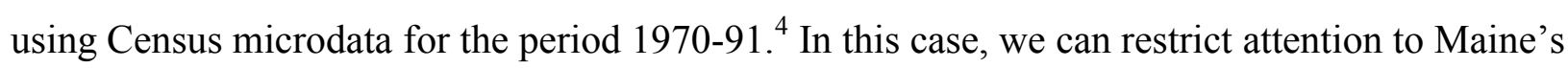
six northernmost counties for an even tighter control group. Both our cell-level and individuallevel analyses generate large estimates of UI program effects. For example, by 1990, 6.1 percent of employed men in Maine's six northernmost counties worked fewer than 27 weeks per year; in New Brunswick that figure was 20.8 percent. Our estimates imply that New Brunswick's more generous UI policy accounts for about two thirds of this differential. For women, 13.8 percent worked less than half the year in Northern Maine compared to 26.2 percent in New Brunswick, with UI policy differences accounting for essentially all of the difference. Overall, our findings suggest that a ten percent UI-induced increase in the income associated with working less than half-year raises the number of persons working less than half year by about ten percent, for an elasticity of one. Estimated elasticities of UI program participation with respect to the income available to part-year workers are about .75 for men and .5 for women.

Methodologically, this paper may be of interest in that it incorporates some advantages of cross-national studies (large and long-lasting variation in program parameters) while avoiding many of their disadvantages. The latter include large and uncontrolled differences in culture and

\footnotetext{
${ }^{3}$ Unemployment insurance has implications for other dimensions of labor supply, including labor force participation. Because much of the useful variation in UI generosity in this paper stems from industry-time interactions (and because non-workers cannot be linked with any particular industry) we chose not to examine these effects in this paper. Trends in annual non-work are also much more likely to be affected by other income support programs (e.g. welfare and disability insurance) that are not explicitly modeled here.
} 
the economic environment, major differences in data collection procedures, and the widespread use of one-dimensional "summary" indicators of program generosity which neglect important details of how policies work (Hamermesh 2002). Our approach examines two very similar regions in different countries - where data collection procedures have been highly comparable for a long time - using a multidimensional measure of program generosity that incorporates virtually all key aspects of the two region's unemployment insurance systems.

\section{Some Facts: Maine, New Brunswick and UI}

Maine is the northeastern most state in the U.S.A, known for its coastal scenery, cold climate, rural character and relatively low incomes. New Brunswick is the Canadian province that borders directly on Maine, known for similar traits. In fact, New Brunswick is a unique province in that it shares a longer border with the United States than with other Canadian provinces. The locations of both regions, including Maine's six 'northern counties', are shown in Figure 1. Both regions are overwhelmingly white and native-born. In 1990, Maine and New Brunswick had total populations of 1.2 million and 740,000 respectively. Over the preceding 50 years, these populations grew by 54 and 59 percent respectively, well behind their respective national averages of 90 and 135 percent. Both regions' incomes were below their national averages as well: from 1945-1991, personal income per capita in Maine was on average 20\% below that of the U.S. while New Brunswick was 27\% below the Canadian average.

Compared to other Canadian provinces that adjoin the United States, New Brunswick is of particular interest for the study of UI for several reasons. First, its relatively low income level means UI replacement rates will be higher, which in turn generates a more dramatic natural experiment. Second, in combination with these low incomes, New Brunswick's small

\footnotetext{
${ }^{4} 2001$ Canadian Census microdata became publicly available in 2004. Between 1991 and 2001, Canada’s UI Act
} 
population and the federal nature of UI in Canada generates levels of program generosity that would likely be unsustainable if UI was self-financing within the region. Thus, New Brunswick offers a rare look at the effects of a very generous income support system relative to the average income level in a jurisdiction. Finally, because of their similar resource bases, New Brunswick and Maine share a history of seasonal employment that predates the introduction of UI to either economy. Thus, the study of these jurisdictions also sheds some light on the process of labor force adjustment. For instance, we can examine the extent to which expansion of UI in Canada helped preserve a (seasonal) "way of life" that was forced into extinction by market forces elsewhere.

Figure 2 provides some indicators of the historical importance of UI in Maine and New Brunswick. Part (a) shows UI expenditures as a share of provincial/state GDP. For New Brunswick, there were large increases during the 1950s and early 1970s, likely reflecting the two major increases in program generosity (to be described in the following section). expenditures in Maine were (a) roughly constant over the entire time period, and (b) much smaller as a share of state GDP. By the end of our sample period, the UI share of GDP in New Brunswick, at 6 percent, was about six times the share in Maine.

Part (b) of Figure 2 compares expenditures on UI to spending on a comprehensive list of other income support programs in both jurisdictions. This Figure clearly shows that UI played a much larger role in New Brunswick's income transfer system than in Maine's. By the end of our sample period, UI constitutes over 25 percent of all transfer income received by individuals in New Brunswick, compared to about 5 percent in Maine. As we argue in more detail below, this 
dominant role for UI in New Brunswick helps explain why the labor supply effects of this single program are detectable at the economy-wide level.

Further confirmation of the pervasive influence of UI in New Brunswick is provided by Table 1. Because Canadian Census years end in ' 1 ' while U.S. Census years end in ' 0 ', and the Census weeks-worked questions refer to the previous year, all our analysis focuses on years ending in ' 9 ' for Maine and ' 0 ' for New Brunswick. Table 1 introduces the convention of referring to, for example, 1989 Maine and 1990 New Brunswick data simply as applying to 1990. Defining 'workers' as anyone with positive weeks worked in the calendar year, Table 1 shows that about 30 percent of New Brunswick's workers received some UI benefits in 1990. This corresponds to about 6 percent for men in Maine, and about 3 percent for women in Maine. Dropping the restriction to workers, Table 1 also reveals that an astonishing 23 percent of all New Brunswick men aged 25-59 received some UI income in 1990. This large fraction of persons receiving UI may also lessen any social stigma attached to it - another factor that might contribute to a larger labor supply response. Finally, Table 1 compares UI participation with that in other income support programs. Only 5 to 6 percent of New Brunswick's workers received transfers other than UI, and only 4 percent of Maine's did. Thus, the number of New Brunswick's workers receiving UI was five to six times the number receiving all other transfers combined, further motivating our focus on UI as the income support program that is most likely to explain weeks-worked differences between these two jurisdictions.

Figure 3 provides historical unemployment statistics for the two jurisdictions under study. Prior to 1953, Maine had a higher unemployment rate than New Brunswick. The unemployment rate in New Brunswick then rose substantially above Maine's in the 1950's, a gap which closed

\footnotetext{
${ }^{5}$ By far the most severe recession during this period took place in the early 1980s. The effect of this recession on total UI expenditures in New Brunswick is clearly visible in Figure 3(a), but is much smaller than the increases that
} 
somewhat by 1970. After 1970, a large and apparently permanent gap re-emerged, with New Brunswick's rate consistently above 12 percent from 1982 onwards, and Maine's consistently

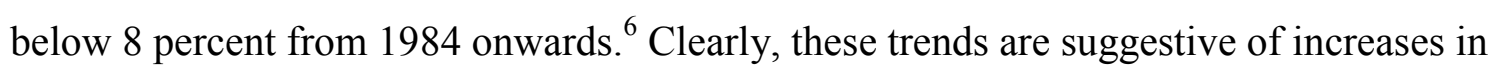
unemployment that took place in response to the two major increases in New Brunswick's UI benefit generosity in the 1950's and 1970s.

\section{Unemployment Insurance Policy}

Our statistical analysis will focus on the calendar years preceding the decennial Censuses in both the U.S. and Canada, from 1940/1 through 1990/1. While we attempt to provide an overall sense of the evolution of UI policy, our primary focus in what follows will be on years ending in '9' for Maine, and years ending in ' 0 ' for New Brunswick. A detailed discussion of UI policy in the two regions is provided in Appendix 1 with the highlights only described below.

\section{a. Maine}

Compared to New Brunswick, the most salient feature of Maine's UI system is its relative stability over the half century between 1939 and 1989. For example, as a result of the 1935 federal Social Security Act, all U.S. states including Maine had an operational UI program in the first year of our data (1939). As in all other states, this program has been state-run and statefunded since its inception. Also since inception, eligibility for Maine's UI benefits (and the weekly benefit amount) is based on total earnings during a one-year-long base period preceding an unemployment spell. The key changes made between 1939 and 1989 include two increases in maximum benefit duration (from 16 to 20 weeks between 1939 and 1949; to 26 weeks by 1959); a shift from calendar-year to a four quarter base period (between 1959 and 1969); extension of

\footnotetext{
occurred in the 1950 s and 1970 s.

${ }^{6}$ The emergence of this large gap mirrors, in a considerably magnified fashion, the well-known emergence of the Canada-US unemployment rate gap (for instance, see Ashenfelter and Card, 1986)
} 
coverage to federal government employees by 1959; to state and local government workers by 1979; the introduction of a dependents' allowance (by 1969), and federal income taxation of UI benefits (by 1979).

\section{b. New Brunswick}

In contrast to the U.S., UI in Canada is administered and financed at the federal level. Thus, UI is not required to be self-funding within New Brunswick, in sharp contrast to the situation in Maine. Also in contrast to most states in the U.S., eligibility in Canada is determined by the number of weeks worked (or, historically, days) rather than total earnings during a base period. Finally, the Canadian program underwent some dramatic changes during our sample period.

As noted, Canada had no operating UI system in 1940. By 1950, UI eligibility depended on the number of days worked during the two years preceding a claim. The 1950 system also included a so-called 'ratio rule', which imposed significant limits on benefit duration for seasonal workers (i.e., those with claims in successive years). In terms of overall generosity, we show below that New Brunswick's UI system was more similar to Maine's in 1950 than in any other year of our data. Aside from converting to a weeks-based qualifying requirement, the key change to the system between 1950 and 1960 was the introduction of an explicit system of Seasonal Benefits, payable only during the winter months but under quite broad conditions (including exhaustion of regular benefits). As we demonstrate quantitatively below, Seasonal Benefits constituted a significant enrichment of Canada's UI program for persons with short work histories.

While Canada's UI system remained relatively unchanged between 1960 and 1970, a second significant expansion of benefits occurred in 1972. While abolishing the explicit Seasonal Benefit program, the new system based weeks of benefit entitlement on weeks worked in the past 
year, with very generous benefits at low levels of weeks, especially in high unemployment regions (including New Brunswick). In such regions, it was possible to qualify for 40 weeks of UI benefits with just 10 weeks of work. Further, workers could continue such a pattern of partyear work year after year, without penalty. ${ }^{\mathrm{E}}$ The 1972 reforms also made UI benefits taxable, and extended the waiting period for benefits (which was one week throughout our sample period for Maine) from one to two weeks. The 1980s saw little change to Canada's UI program.

\section{Empirical Analysis: Cell means, 1940-91}

\section{a. Conceptual Framework}

As noted, a distinguishing feature of this paper is our interest in UI's effects on the distribution of annual weeks worked in the entire population of a region's workers. This differs from most studies, which focus on a number of outcomes (such as unemployment duration) conditional on a worker's becoming unemployed. In these studies, the population potentially affected by UI is by definition a relatively small share of the workforce. We $_{\text {We interested in }}$ estimating impacts that could operate both through the extension of existing unemployment spells, and through processes that lead to the initiation of unemployment spells.

With the above goal in mind, we use a simple static labor supply model as our basic conceptual framework. This model is in the spirit of Moffitt and Nicholson's (1982) with a (significant) change of interpretation. Moffitt and Nicholson consider a decision made by workers at the time of job loss. Thus, their analysis applies only to workers who have already initiated an unemployment spell, and assumes that workers can choose to end that spell at any

\footnotetext{
${ }^{7}$ In some parts of the country this practice became known, unofficially, as "Lotto 10-40", i.e. work ten weeks, then claim UI for 40.

${ }^{8}$ As Krueger and Meyer (2002) point out, a much smaller number of studies focus on the effect of the UI system (for the most part its experience-rating provisions) on the rate of layoffs. A few Canadian studies (e.g. Baker and Rea 1998) examine UI's effects on the length of employment or job spells, but do not combine this analysis with UI effects on unemployment spell length.
} 
point by taking a job. We abstract even further from the dynamics of job search, hires and layoffs by assuming that any worker, whether employed or unemployed, can choose the number of weeks worked per year with any non-work weeks compensated - according to benefit eligibility formulas - by unemployment insurance.

Maine and New Brunswick severely restrict UI eligibility for workers who quit their job. We ignore these restrictions in the analysis, and thus our framework implicitly assumes that workers can find seasonal or limited-term contract jobs that match their desired durations (or indeed that such jobs are supplied by the labor market in response to the UI system). Equivalently, our model also describes an environment where workers can induce firms to lay them off when this is convenient to the worker, or that employers agree to "re-label" quits as layoffs. ${ }^{9}$ Incidentally, there is evidence of all these practices in Canada. For example, Green and Sargent (1998) show how jobs tend to end (via layoffs) when UI eligibility is established; Kuhn and Sweetman (1998) provide evidence of the "relabelling" of separations. Harris (1998) shows how some employers even created a job-sharing system to maximize employees' UI eligibility ${ }^{10}$ Since it may take time for markets to adapt in such a sophisticated way to the UI program, our longer-run perspective may yield different results than most existing approaches.

We recognize that this is a highly abstract model that ignores the job search, hiring and layoff processes. To an important extent, however, worker's limited control over the length of their employment or unemployment spells is addressed in our analysis by the broad weeks-worked categories used. For example, in this section we model workers as choosing between 'part year'

\footnotetext{
${ }^{9}$ Canada's UI system has no experience rating; thus employers face no marginal tax cost when they re-label a separation. This is not the case in Maine, where at least a minimal amount of experience rating does occur. Relatedly, we note that quits are a small fraction of separations leading to unemployment in both Canada and the US; thus UI disqualifications due to quitting are unlikely to be quantitatively important in either region.

${ }^{10}$ According to Harris, "In some cases fish plants and make-work projects would hire workers for a certain number of weeks and then lay off those workers and hire others, so they'd all have qualification for unemployment insurance" (p. 176).
} 
and 'full-year' work, with the attractiveness of these broad weeks-worked categories depending on the income and leisure available to a typical worker in that category. ${ }_{\text {Also, note that if we }}$ detect a strong and significant effect of UI on weeks-worked distributions using this highly abstract voluntary labor supply model, workers may have more control over both their job and unemployment durations than we might otherwise suspect.

Our aggregate pre-1970 data only allows us to consistently distinguish two annual weeks worked categories. Suppose that each worker, $i$, faces two labor supply options: 'full year' or 'part year'. Each of these options is associated with a fixed annual amount of leisure, denoted $L^{F}$ and $L^{P}$. Let the annual income received by full- versus part-year workers respectively be $Y_{i}^{F}$ and $Y_{i}^{P}$. These income levels vary across individuals for a variety of reasons including changes in policy, skill differences across workers, and UI's differential impact by skill level, region, and industry. Next, let the utility of working full year be given by the Cobb-Douglas function:

$$
U\left(Y_{i}^{F}, L_{i}^{F}\right)=\alpha \ln Y_{i}^{F}+\beta \ln L^{F}+\varepsilon^{F} \equiv \alpha y_{i}^{F}+\beta l^{F}+\varepsilon^{F}
$$

Similarly, let the utility of working part year be given by:

$$
U\left(Y_{i}^{P}, L_{i}^{P}\right)=\alpha \ln Y_{i}^{P}+\beta \ln L^{P}+\theta^{P} X_{i}+\varepsilon_{i}^{P} \equiv \alpha y_{i}^{P}+\beta l^{P}+\theta^{P} X_{i}+\varepsilon_{i}^{P}
$$

In equation (2), $\theta^{P} X_{i}$ represents the effects of observable personal characteristics on the relative utility of part-year work (any $X$ 's that affect the utility of both choices the same way do not change observed behavior; thus only relative effects are identified). Combining (1) and (2), individual $i$ prefers to work part-year iff:

\footnotetext{
${ }^{11}$ In fact, in a world where workers have limited control over exact job duration, the search in some studies (e.g. Green and Riddell 1997, Green and Sargent 1998) for "spikes" in very narrow weeks-worked categories (essentially single weeks of unemployment duration) could lead to significant underestimates of workers' responses to UI. All told, we view our use of a multinomial choice model among broad weeks-worked categories as a useful alternative
} 


$$
\varepsilon_{i}^{F}-\varepsilon_{i}^{P}<\alpha\left(y_{i}^{P}-y_{i}^{F}\right)+\beta\left(l^{P}-l^{F}\right)+\theta^{P} X_{i}
$$

Given specifications for the distributions of $\varepsilon_{i}^{F}$ and $\varepsilon_{i}^{P}$, (3) can be estimated via maximum

likelihood from microdata. In the latter case, a dichotomous dependent variable (whether an individual works part-year) is regressed on a vector of personal characteristics $(X)$ and on $\left(y_{i}{ }^{P}-\right.$

$y_{i}^{F}$ - the log of the ratio of part-year to full-year income. 12 UI policy enters our model by

changing the ratio of part-year to full-year income (henceforth 'relative income'). For grouped data, (3) implies a relation between the fraction working part year in a cell and the regressors on the right-hand side, whose functional form depends on the distributions of $\varepsilon_{i}^{F}$ and $\varepsilon_{i}^{P}$.

\section{b. Data}

We collected information on the fraction of employed persons working between 1 and 39 weeks, and between 40 and 52 weeks, for every census year between 1940 and 1990 in both regions. For Maine in all years, and for New Brunswick beginning in 1970, this information was constructed from public-use microdata files. Because census microdata do not exist for Canada prior to 1970, we rely on published sources for those years. Across countries and years, the finest level of disaggregation available is by gender and broad industry group. The unit of observation for this exercise is therefore industry/gender/region/year cells. Appendix 2 discusses data comparability across census years and between countries.

Sample sizes in the 1971 Canadian census, and limited industry disaggregation in all the post-1970 Canadian public use files, limit the number of industries for which we can calculate

to hazard models, which has the additional advantage of allowing us to combine choices affecting both job durations and unemployment durations into a single summary estimator.

${ }^{12}$ Because the terms $\beta\left(l^{P}-l^{F}\right)$ are absorbed into the constant term in $\theta^{P}, \beta$ is not identified. The model is easily extended beyond Cobb-Douglas preferences by allowing the effect of $\left(y_{i}{ }^{P}-y_{i}{ }^{F}\right)$ to be nonlinear. Experiments with higher-order polynomial terms of this variable yielded similar results. 
cell means with a reasonable degree of precision. Given these constraints, we are left with 6 industries per year for women (trade, services, finance/insurance/real estate, transportation/ storage/communication/utilities, manufacturing, and public administration) and 9 for men (the above plus agriculture, construction and primary) for a total of 6 industries * 6 years $* 2$ regions $=72$ female observations and $9 * 6 * 2=108$ male observations. The sample is all wage earners over the age of 15 with at least one week of work in the previous calendar year. $\frac{13}{13}$

Table 2 presents employment-weighted means of the relative income variable. These are computed using each cell's weekly wage and various weeks worked assumptions. We use 52 weeks to represent the 'full-year' (40-52 weeks) option, and two alternative reference points (20 and 30 weeks) to represent the part-year (1-39 weeks) option. 4 UI benefits are added to part-year income based on prevailing UI parameters. ${ }^{15}$ Part-year income varies cross-sectionally within a region because wage levels (and hence UI replacement rates) vary across industries, and because not all industries are covered by UI in all years. It varies over time both due to UI policy changes and to wage level changes at the industry level.

One policy change that is clearly visible in Table 2 is the introduction of UI in New Brunswick after 1940. New Brunswick has the minimum possible values of the relative income variable $(20 / 52=.385 ; 30 / 52=.577)$ in 1940 , and higher levels afterwards. Maine's UI system was already in place by 1940 , and according to our measures remained slightly more generous than New Brunswick's in 1950 as well. That said, Table 2 reveals that - especially using the 20-

\footnotetext{
${ }^{13}$ Self-employed persons are excluded. With the exception of fishermen in Canada, the self-employed are not eligible for UI in either region. In both regions and all years, industry designations refer to the longest job held during the previous calendar year.

${ }^{14}$ We examined the continuous distribution of weeks worked for those years where it was available; the median within the 1-39 weeks category was between 20 and 30 weeks in all cases. We also replicated the analysis using 15 , 25 and 35 weeks to represent the 1-39 weeks category. There were no major differences.

${ }^{15}$ In reality not all eligible workers actually apply for and receive UI benefits (see for example Blank and Card, 1991). Since take-up is endogenous (Anderson and Meyer 1997), we simply use the legislated benefits an eligible
} 
week parameters - 1950 is the Census year in which the overall UI subsidy to part-year work was most similar between New Brunswick and Maine.

By 1960, New Brunswick’s UI system had become more generous than Maine’s; particularly for women whose lower wages generated higher benefit replacement rates. The decline in generosity between 1960 and 1970 is attributable to an inflation-induced decline in the real value of a fixed nominal maximum benefit level. Canada's 1971 UI Act is also clearly visible in Table 2. Interestingly, according to the 20 -week specification, the largest decadal change in UI's subsidy to part-year work occurred not in 1971, but between 1950 and 1960 - a rise of (.580$.441=) .139$ for men, and $(.614-.455=) .159$ for women, both in New Brunswick ${ }^{16}$ Converting these numbers into total weeks of income received per week worked gives a clearer perspective on the magnitude of these policy changes. As an example, for New Brunswick women in 1950, 20 weeks of work yielded $(52 \times .455=) 23.7$ weeks of income when UI benefits are included; by 1960 this was $(52 \times .614=) 31.9$ weeks. The statistical analysis which follows addresses whether the benefit changes shown in Table 2 affected the tendency to work part-year.

Table 3 shows employment-weighted means of our dependent variable by gender, region and year. In 1940, despite a modest UI program in Maine, employed men exhibited roughly similar propensities to work part-year in the two jurisdictions under study: 36 percent in New Brunswick and 33 percent in Maine. Over the next five decades, men's part-year work continued at this high level in New Brunswick, while declining substantially (to 22 percent) in Maine. For women, the divergence between New Brunswick and Maine is more dramatic. In 1940, before the advent of UI in New Brunswick, working women in Maine were 8 percentage points more

worker would receive if he/she applied for them as a more exogenous measure of benefit generosity. Our estimates can therefore be seen as underestimates of the response that would occur if all eligible workers claimed UI.

${ }^{16}$ Coincidentally, a change of exactly the same magnitude occurred between 1970 and 1980 for women; for New Brunswick's men the 1970-1980 change was .135. 
likely to work part-year than women in New Brunswick (38 versus 30 percent). Five decades later, part-year work had fallen to 31 percent in Maine, while increasing to 40 percent in New Brunswick. Thus, by the end of the period the rankings of the regions were dramatically reversed.

\section{c. Results}

Weighted least-squares estimates of equation 3 are presented in Table $4 .{ }^{17}$ All specifications include fixed effects for industry, year, and region; separate regressions are estimated for men and women. 18 To produce estimates that are representative of the entire labor force, all regressions are weighted by year-specific industry shares in employment. The results in all columns show that part-year work is more common in agriculture, construction and primary industries relative to manufacturing (the omitted category), and less common in the finance, government, and transportation industries. Time trends in part-year work implied by the estimated year effects are mostly downward, but vary across specifications. Finally, note that while the estimates using 20- versus 30-weeks to represent part-year work are quite similar, the 20-week version of the model fits our data considerably better for women. This could be because, relative to men, a larger share of part-year women work 20 weeks rather than 30 weeks. In the discussion below, we will primarily refer to the 20 -week results.

Concerning the UI policy variable, row 1 of Table 4 shows that the relative income associated with part-year work has a positive effect on the share of workers working part year in

\footnotetext{
${ }^{17}$ Results based on a logistic specification (i.e. using the log-odds ratio in the cell as the dependent variable) were very similar; we show the linear results for greatest ease in interpretation. Grouped-data logit is not feasible because, for those cells based on published data, we do not have access to the underlying number of observations from which the cell proportions were calculated.

${ }^{18}$ We experimented with specifications that included a full set of region-year interactions; here identification would come only from those aspects of region-specific UI changes that had differential impacts across industries. For both men and women, the resulting coefficients were statistically insignificant with very high standard errors. Thus, in the cell-level analysis, there does not appear to be enough cross-industry, within-jurisdiction variation in UI replacement rates to use this identification strategy.
} 
all specifications; this effect is highly significant when the 20 -week UI parameters are used. To interpret the size of these coefficients, recall from Table 2 that the largest decadal change in the 20-week version of our policy variable occurred between 1950 and 1960; in log terms, these translate into a change in $\ln \left(Y_{i}^{P} / Y_{i}^{F}\right)$ of $\ln (.580)-\ln (.441)=.274$ for men and $\ln (.614)-\ln (.455)$ $=.300$ for women. Applying the relative income coefficient from Table 4, this translates into a predicted change in the share working part year of .047 for men and .143 for women. Using actual 1950 part-year shares as a base, this would raise the share working part-year from 28 to 33 percent for men, and from 15 to 29 percent for women.

Clearly, the above effects are large and economically meaningful, especially for women. Are these magnitudes plausible? To examine this question, it is important to first consider the nature of the implicit wage change associated with the UI policy changes studied in this paper. This is illustrated in Figure 4. If a person works all year, they will not receive any UI benefits regardless of the generosity of the UI system. Normalize income in this situation to 1 . UI changes in New Brunswick between 1950 and 1960 raised men's relative income from part-year work from .441 to .580 . Thus, in contrast to the usual case of a wage increase, wage changes associated with more generous UI have unambiguous predicted effects on labor supply: assuming leisure is a normal good, both income and substitution effects imply a greater incidence of part-year work.

Next, consider the magnitudes of the effective wage changes implied by the UI reforms in our data. For the case illustrated in Figure 4 (New Brunswick men between 1950 and 1960), the implicit percentage wage change is about 27 percent $((.580-.441) /(1-.5(.580+.441))$. Assigning 20 weeks of work to part-year workers and 52 to full-year workers, our predicted increase of 4.7 percentage points in part-year work translates into a predicted decline in 1.5 weeks of work per year, (from 43 to 41.5 ) which in turn translates into a labor supply elasticity of 0.13 . The same 
calculation yields an elasticity of 0.30 for women. While these are economically meaningful, they are not implausible in magnitude. Overall, despite the obvious search frictions affecting weeks worked in the real world, and the large array of UI program regulations designed to prevent workers' labor supply adjustments to the UI system (including disqualifications for job quitters and job search requirements for the unemployed), substantial labor supply responses are estimated. Further, even the relatively modest labor supply elasticities estimated here can correspond to large responses of the incidence of part-year work to policy changes, with correspondingly dramatic implications for the number of persons participating in an incomesupport program and for the costs of running such programs.

To see the latter point, note that - by definition - full-year workers cannot claim UI, and suppose (as Anderson and Meyer 1997 have shown) that the UI take-up rate responds positively to benefit generosity. It follows that the elasticity of part-year work with respect to UI benefit levels provides a lower bound estimate of the elasticity of program participation with respect to the benefit level. ${ }^{19}$ For men, we estimate that a 27 percent increase (from .441 to .580 ) in the amount of income associated with part-year work generates a 15.5 percent (from 28 to 33) increase in the share of men choosing this option, for an elasticity of .57. For women, this elasticity is much higher at 2.09. Clearly, responses of this magnitude cast major doubt on forecasts of program expenditures that assume no behavioral responses by workers.

Although direct comparisons are hard to make (existing estimates tend to focus on very specific outcomes, such as employment durations), the above elasticities seem large compared to previous studies of the Canadian UI system (e.g. Green and Riddell 1997, Baker and Rea 1998), including those which focus on seasonal work and the Atlantic Provinces (e.g. Green and Sargent

\footnotetext{
${ }^{19}$ Let $P=T^{*} P Y$, where $P$ is UI program participation, $P Y$ is the share working part-year, and $T$ is the take-up rate. It follows that $\mathrm{d} \log P / \mathrm{d} \log B=\mathrm{d} \log T / \mathrm{d} \log B+\mathrm{d} \log P Y / \mathrm{d} \log B$, where $B$ is an indicator of UI benefit generosity.
} 
1998). We attribute this difference to three main factors. First, as in other countries, existing studies of Canadian UI also tend to restrict their attention to short-run responses. 20 Second, the use of Maine as a control group holds constant a secular downward trend in part-year work in both jurisdictions. In a study focused on New Brunswick only, such time trends would lead to an underestimate of true UI policy effects. Finally, existing Canadian studies pay relatively little attention to the dramatic increases in seasonal UI benefits that occurred before the well-known 1971 Act. Not accounting for these earlier subsidies tends to overstate the magnitude of Canada's 1971 reforms, thus understating the labor supply elasticities associated with them.

\section{Empirical analysis: Microdata, 1970-91}

\section{a. Conceptual Framework}

As noted, public-use microdata files are only available for Canada from 1970 onwards. Thus, for the years 1970-91, we can examine the determinants of part-year work at the individual worker level. To compensate for this shorter (but still long compared to most other studies) time span, the microdata have four principal advantages. First, we can exploit more sources of variation across individuals and time in our relative income variable; in particular, we can now allow relative income to vary with the respondent's education and the presence of dependents. Second, as noted, we restrict our attention throughout this section to Maine's 'northern counties', which are even more similar (than Maine as a whole) to New Brunswick. Third, we can conduct a separate analysis of a low-education sample, to see whether responses to UI are higher in this subpopulation. Finally, and most importantly, we can examine a more detailed distribution of weeks worked than the under and over 40 weeks split. 21 If we can show that the particular weeks-worked categories where UI subsidies increased the most also experienced the largest

\footnotetext{
${ }^{20}$ One exception is MacLeod and Lemieux 's (2001) study of learning effects among repeat users.
} 
increases in 'popularity' among workers, our confidence that UI policy changes had causal effects on the weeks-worked distribution would be considerably increased.

The weeks worked information available allows us to assign every individual to one of four weeks worked options: 1-13, 14-26, 27-39 and 40-52. These are the most detailed categories that are consistent across regions and time. Thus, we require a method of estimating the distribution of workers across four weeks-worked categories. Fortunately this is possible via a straightforward generalization of equations (1) - (3). Instead of two weeks-worked categories ( $P$ and $F$, for part- and full-year), let there now be four; labeled with superscripts 1, 2, 3 and 4 . Let category 1 continue to represent full-year work (still defined as 40-52 weeks). Continuing to use this as the reference category, equation (1) remains unchanged except for a change of superscript. The remaining three categories each will have utility given by their own version of equation (2). If the four ,'s have independent and homoskedastic Weibull distributions 2 , equation (3) becomes McFadden's conditional logit model, where the $X$ 's represent characteristics that vary across persons only, while the income $(Y)$ variables vary both across persons and the four choice categories. Finally, since an equal increase in $\ln (Y)$ across all four categories leaves optimal choices unchanged, we can normalize $\ln \left(Y^{F}\right)$ to 1 in (1), which transforms the income variables in (2) to $\alpha \ln Y_{i}^{j}-\alpha \ln Y_{i}^{1}=\alpha \ln \left(Y_{i}^{j} / Y_{i}^{1}\right), j=2,3,4$. Thus, the correct choice-specific policy variable is the $\log$ of the ratio of person $i$ 's income if he/she chooses the relevant weeks-worked category to his/her income if she worked full year.

\footnotetext{
${ }^{21}$ Some more minor advantages of the microdata are a more detailed set of control variables, and the ability to incorporate additional UI rules in each region.

${ }^{22}$ Most other specifications for the distribution of the errors are computationally impractical. In early work on this data, we estimated a Cobb-Douglas model with only a single error term (representing the person's "tastes for work") rather than four. This single-, model consistently did a poorer job of fitting empirical weeks-worked distributions.
} 
Two practical issues arise in computing the above relative income variables. One is the level of weeks to "represent" each category in computing UI benefits. ${ }^{23}$ We use the midpoints (20 and 33) for the 14-26 and 27-39 weeks-worked categories respectively, and assume full-year work (52 weeks) for the final category - as we did in the cell-level analysis. The data imposes an important constraint on our analysis with respect to the 1-13 week category. If we adopt a midpoint of 7 weeks then no individual in this category would receive UI in any region or year. However, with 13 weeks of work, a substantial proportion of Maine workers would qualify albeit with a relatively minor amount of UI income - and all workers in New Brunswick in 1980 would qualify for a very generous benefit. 4 To address this issue, we examined the continuous distribution of weeks worked within the 1-13 week category in both New Brunswick and Maine for 1980. Based on this, we model all workers in the 1-13 category as working for 12 weeks, but model UI income in this category as equal to half of what such a worker would qualify for. 25

A second practical consideration - specific to microdata - is the effect of measurement error in weeks worked on our estimates (this is largely eliminated in the cell data by the law of large numbers). For distinct but related reasons to the classic "division bias" problem (Borjas 1980),

\footnotetext{
${ }^{23}$ Data constraints (in particular the categorical nature of New Brunswick's 1970 weeks-worked information) prevent us from computing benefits for every integer level of weeks worked, then taking a weighted average thereof. In addition, using a fixed number of weeks avoids the endogeneity associated with changing weeks distributions with in a category. Finally, focusing on just a few representative weeks levels has allowed us to ensure that all details of a very complex UI system are accurately modeled in each region and year.

${ }^{24}$ Further, in 1990 for New Brunswick, the unanticipated and 'accidental' suspension of the variable entrance requirement in Canada results in individuals who previously qualified with 10-13 weeks worked being ineligible for the 1990 benefit year only (see Green and Riddell, 1997; Baker and Rea, 1998). Given that the weeks worked variable in the 1991 Canadian census refers to the 1990 calendar year, we need to handle this in some way. As described below, we allocated some UI to people in the 1-13 weeks category in 1990-specifically, a weighted average of what they would have had with and without the suspension - on the grounds that their behavior cannot have perfectly reflected this unanticipated and temporary policy change.

${ }^{25}$ In New Brunswick, $50 \%$ of men in this category were at 9 weeks or less (where no one would qualify for UI in either region), with $20 \%$ at 10 weeks, $5 \%$ at 11 weeks, $20 \%$ at 12 weeks, and $5 \%$ at 13 weeks. The distribution is virtually identical for women, and also very similar for Maine - where men and women have an identical distribution at $54 \%$ at 9 weeks or less, $13 \%$ at 10 weeks, $3 \% 11$ weeks, $25 \%$ at 12 weeks, and $5 \%$ at 13 weeks.
} 
this may bias our estimates of UI program effects. ${ }^{26}$ To address this problem, we use the individual's predicted rather than actual relative earnings, where predictions are based on the following variables in addition to the $X$ 's: a New Brunswick dummy interacted with 1980 and 1990, all the industry dummies interacted with New Brunswick, all the industry dummies interacted with New Brunswick and a post-1970 dummy, and education interacted with New Brunswick and a post-1970 dummy. ${ }^{27}$ This strategy is based on the notion that New Brunswick's 1971 UI policy changes had effects on the relative attractiveness of weeks-worked categories that varied by jurisdiction, industry and worker skill level. These across-group policy change differentials are plausibly exogenous to the measurement error in individual weeks worked and can therefore be used to identify the effects of the relative income variable.

\section{b. Data}

We use the New Brunswick observations in the 1\%, 2\%, and 3\% national Public Use microdata files for 1970, 1980 and 1990 respectively. For Maine, we use the 1\% sample in 1970

\footnotetext{
${ }^{26}$ Recall that the relative income variable is calculated, for each individual using that individual's estimated average weekly earnings. Further, average weekly earnings are computed by dividing annual earnings by annual weeks worked. Loosely speaking, our regression in the dichotomous case is thus specified as follows:

$$
\left.\operatorname{Prob}(\text { Part-year })=f\left(\gamma_{0}+\gamma_{1} R \text { [annual earnings/annual weeks }\right]+\gamma_{2} X\right),
$$

where the function determining relative income, $R$, is decreasing in its argument because of the maximum UI benefit level. Suppose that an individual's weeks worked were misclassified below their true level. This raises our computed weekly wage (the argument of $R$ ) and reduces the computed relative income from working part year. Since the same negative measurement error raises the dependent variable, a spurious negative correlation between relative income and the incidence of non-work is introduced.

${ }^{27}$ To reduce the impact of measurement error we also eliminated weekly wage outliers; specifically, in each region/year we drop the top 1 percent and bottom 5 percent of the calculated wage distribution.

${ }^{28}$ Another advantage of using predicted relative earnings is that it addresses estimation problems stemming from unobserved individual 'ability' as well. If unexplained individual weekly wage differences ('ability') are positively correlated with unobserved differences in tastes for work, a cross-sectional OLS coefficient on our relative income variable will overstate the causal effects of relative income on weeks worked. By removing the idiosyncratic portion of individual earnings from the calculation of an individual's relative earnings in different weeks worked categories, our procedure eliminates this form of 'ability bias' as well.
} 
and the 5\% state samples for 1980-90. 29 In addition, we restrict our sample to persons living in Maine's six 'northern counties' only; we henceforth refer to this area as Northern Maine. As noted, details of variable construction for both the cell-means and microdata, including issues of comparability across countries and across years, are provided in Appendix 2.

Some basic descriptive statistics of our estimation sample are provided in Tables 5 and 6.0 For context, these Tables also show statistics for all of Maine in addition to the six northern counties. On virtually all dimensions, Northern Maine is more similar to New Brunswick than is Maine as a whole. In addition, the working populations of Northern Maine and New Brunswick were of almost identical ages, and had similar levels of education. There were some differences in family structure (marriage and children are more common in New Brunswick, perhaps as a consequence of generous $\mathrm{UI}^{31}$, which are expected to raise men's annual work weeks, but to reduce women's. While there were some differences in industry mix - in particular, the primary sector was more important in New Brunswick while manufacturing was more important in Northern Maine, at no time in either jurisdiction under study did the primary sector (essentially fishing and logging) employ more than nine percent of men, or two percent of women.

\section{c. Results}

Coefficients from conditional logit estimation of equation 3 are reported in Table 7 . In addition to the control variables shown (whose role is to allow for a different choice-specific intercept for each year of data and each jurisdiction), all columns of Table 7 include a full set of

\footnotetext{
${ }^{29}$ We use Stata's "p-weight" option to adjust our estimates for these differences in sampling rates across countries and years. Thus our estimates are representative of a worker drawn at random from the combined populations of Northern Maine and New Brunswick over all three years of our data.

${ }^{30}$ Note that the statistics reported in Tables 1 and 2 pertain to persons aged 25 through 59 with at least one week of employment in the relevant calendar year-the sample used in Section 5 of the paper below.

${ }^{31}$ Our estimates of UI effects will condition on these family variables; of course to the extent that these variables respond to UI incentives our estimates will tend to understate long-run UI effects on weeks worked.
} 
industry effects for each weeks-worked category. Further, columns 2 and 4 include controls for all the variables summarized in Tables 1 and 2: age, marital status, children, school attendance, education, part-time work. While not reported, these variables have effects on the choicespecific propensities that are, in almost all cases, strongly in line with expectations (e.g. higher education reduces the attractiveness of all part-year categories relative to the baseline, full-year category).

Turning to the UI policy variable, the results in Table 7 provide strong evidence that, ceteris paribus, a UI-induced increase in the relative income in a weeks-worked category makes it more likely to be chosen ( $t$-statistics on this variable vary across specifications from 2.8 to 9.1$). \frac{32}{}$ As conditional logit coefficients do not provide useful measures of the effects of a regressor on the expected distribution of outcomes, Tables 8 through 10 display various actual and predicted weeks-worked distributions calculated from the coefficients in Table 7.

Table 8 assesses how closely the conditional logit model fits the actual weeks-worked distribution across time and regions. Part (a) focuses on men and shows that full-year work was more common in Northern Maine than in New Brunswick in all years under examination (this is not surprising given the pre-existing UI differences studied in the previous section). By 1990, only about 72 percent of employed 25 to 59-year old New Brunswick men worked full year, compared to about 88 percent in Northern Maine. 33 In addition, while full-year work declined over time in both regions between 1970 and 1990, it declined to a greater extent in New Brunswick than Northern Maine (about 7 versus 3 percentage points) despite starting at a lower

\footnotetext{
${ }^{32}$ As in Section 4's analysis of cell means, we experimented with a specification that included controls for a full set of year- region interactions. In contrast to the cell-level results (see note 18), in the microdata case the estimated policy effects did not attenuate or lose statistical significance when these interactions were included.

${ }^{33}$ These figures for full-year work differ from those in Table 3 for two reasons: the restriction to ages 25-59 and the restriction to Northern Maine. We find it noteworthy that the interregional differences remain so stark even when these restrictions are imposed.
} 
base. Moreover, substantial increases occurred in the two lowest weeks-worked categories, 1-13 and 14-26, in New Brunswick. Part (a) also shows the weeks-worked distributions predicted by our model for men. 34 Overall, the model fits these distributions very well. In 15 of 24 possible cases the prediction is within a single percentage point of the actual, and in no case is the model off by more than three percentage points.

Actual versus predicted values for women are shown in part (b) of Table 8. Similar patterns are evident, but against the background of an overall increase in labor force participation and full-year work. There are large increase in the fraction of New Brunswick women working 1-13 weeks (particularly between 1970 and 1980), and 14 to 26 weeks per year; an amount of work that entitles one to a full year of UI benefits in New Brunswick, but much less in Maine. As for men, the model fits the actual weeks-worked distributions remarkably well in both jurisdictions.

\section{d. Predicted Policy Effects: New Brunswick’s 1971 UI Act}

To examine the role of UI policy, Table 9 poses the following question: what would have happened in New Brunswick if the 1971 UI Act had not been implemented? The results are striking. For men, the simulation indicates that instead of declining by 7 percentage points, fullyear work would have remained relatively constant at around 80 percentage points over the next two decades. Thus, the 1971 UI Act can account for virtually all of New Brunswick's (absolute and relative) decline in full-year work among men. Moreover, absent the 1971 UI Act, the large increases in the 1-13 weeks worked (from 1.3 to 4.5 percentage points) and 14-26 weeks worked (9.3 to 15.6) categories would not have occurred.

\footnotetext{
${ }^{34}$ Predicted probabilities across all four choices were computed for every person in our sample, then averaged across persons by year and region.
} 
For women, a somewhat different story emerges. Instead of a relatively minor increase in full-year work, the fraction of women working full-year would have increased by 14 percentage points if New Brunswick's 1971 policy change had not occurred. The 1970 part-year weeks worked distribution in New Brunswick is still skewed towards 14-26 weeks (relative to Northern Maine), but, as the previous Section suggests, this could be due to pre-existing UI policy differences between the regions. In summary, the 1972 UI reforms appear to have dramatically increased the incidence of part-year work in New Brunswick. For women in particular, these effects would not be apparent in a single-country study that did not use Northern Maine as a control group.

As in the two-outcome model, it is instructive to compute the labor-supply and other elasticities implied by our estimates. To derive a summary metric of the overall effective wage change associated with New Brunswick's 1972 UI reforms, consider the budget constraints facing an average New Brunswick woman in 1980 under two different legislative regimes, 1980 and 1970. These budget constraints are depicted in Figure 5 (the numbers entered into the Figure are the means of the policy variables used in the Table 9 simulations). Under 1970 rules, the implicit weekly wage associated with the 1-13 weeks worked category, measured in weeks of income per week of work, is one. This is because no individual working between 1 and 13 weeks was entitled to UI under New Brunswick’s 1970 rules, 12 weeks of work yielded 12 weeks, or $12 / 52=.231$ years worth of income (recall that 12 weeks represents the $1-13$ week category).

Under the 1980 rules, this implicit wage rate had fallen from one to $(1-.448) *[52 /(52-12)]=$ .72 weeks of income per week worked, a 33 percent effective wage decrease (using an average of initial and final values as a base to calculate percentages). The same calculations applied to the 
14-26 and 27-39 weeks worked categories yield percentage wage declines of 58 and 41 percent respectively. Taking a simple average of these, New Brunswick's women faced roughly a 44.1 percent effective decline in the returns to working an extra week of the year, due to the 1972 UI reforms. What elasticities does this imply? Continuing to use 52, 33, 20 and 12 weeks to represent the four weeks-worked categories, the 1980 policy reforms led to a 9.6 percent decline in annual weeks worked (from 42.5 to 38.7 ), implying a labor supply elasticity of 9.6/44.1 = .22. For men, the same calculations yield an elasticity of .13. These values are remarkably close to our estimates from the previous section's model, .30 and .13 for women and men respectively.

As before, we also compute frequency-of-choice elasticities with respect to the income associated with a choice. Focusing on the bottom two weeks-worked categories (1-13 and 1426), women's elasticities are 1.06 and .68 respectively; men's are 1.34 and 0.99 respectively. Thus, a ten percent increase in the total income associated with working 1-13 weeks implies an increase of more than ten percent in the share of workers in that category. Combining the bottom two categories, we estimate an elasticity of about one (1.04 for men, .91) for both men and women. Thus, for both men and women, increasing the income associated with working less than half year by ten percent raises the number of men or women working under half year by about ten percent as well. ${ }^{35}$ Clearly, these estimates suggest large responses of UI program participation, and expenditures, with respect to program generosity.

On one level, we should not be surprised if New Brunswick's 1972 UI reforms led to an increase in UI program participation. The new rules extended UI entitlements to workers with very short histories who previously did not qualify for the program. Thus, a participation (and expenditure) increase would have occurred even in the absence of any behavioral responses to

\footnotetext{
${ }^{35}$ Combining the bottom three categories yields an estimate of UI effects on 'part-year' (under 40 weeks) work that is comparable to those obtained in our cell-level analysis. These elasticities are .90 for men and .74 for women.
} 
the policy change. Since our interest here is in behavioral adaptation to legislation, we net out the above, purely mechanical "entitlement" effects by computing changes in UI participation under a fixed (1980) set of UI rules. Since, under the 1980 rules, about half the workers in the 113 week category qualifed for UI, our estimate of the number of UI program participants equals the number of workers in the 14-26 and 27-39 week categories, plus half the number in the 1-13

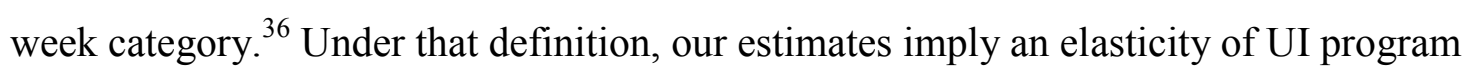
participation with respect to the wage of .47 , and of paid UI weeks with respect to the wage of .34 for women. For men, these numbers are .72 and .67 . Elasticities with respect to the average income associated with "part-year" (under 40 weeks) work are similar: .80 and .74 for men, and .57 and .41 for women. In other words, raising the income associated with part-year work by 10 percent is predicted to raise the number of men receiving UI benefits by 8 percent, and the number of UI benefit weeks paid to men by 7.4 percent. $\frac{37}{3}$

\section{e. Predicted Policy Effects: International Comparisons}

In the spirit of understanding the contribution of income support policies to international differences in work activity (e.g. Prescott 2004; Alesina et al 2005), we also ask: "What would happen if New Brunswick adopted Maine’s UI system?” The results, presented in Table 10, show that 80 percent of New Brunswick's working men would be working full year in 1990 (compared with 72 percent who actually did so, and compared with 88 percent of Northern Maine men who did so). Thus, UI policy alone explains half of men's 16 percentage point crosssectional gap in full-year work between these two jurisdictions in 1990. If New Brunswick had

\footnotetext{
${ }^{36}$ If only a fixed fraction of UI-qualified workers actually participate in the program, our computed elasticities are unaffected. If the UI take-up rate among qualified workers increases with the benefit level, the elasticities presented below underestimate the magnitude of the response.

${ }^{37}$ These UI take-up elasticities are larger for men than those obtained from the previous section's two-outcome model, but smaller for women (they were .57 and 2.09 respectively for men and women). We place more weight on the current numbers since they are based on a more detailed simulation of the change in predicted work weeks.
} 
Maine's UI system, 75 percent of its working women would have worked full year in 1990 (compared to 65 percent who actually did so, and compared with 76 percent of Northern Maine women who did so). UI policy therefore explains all of women's 16 percentage point crosssectional gap in full-year work between these two jurisdictions in 1990.

Focusing on the share of workers who put in less than a half year of work, Table 10's predictions are even more dramatic. For example, according to Table 8, in $1990(2.2+3.9=) 6.1$ percent of Northern Maine's working men worked fewer than 27 weeks; in New Brunswick that figure was more than three times as high at 20.8 percent. From Table 10, only $(1.0+10.4=) 11.4$ percent of New Brunswick's working men would work less than half year if New Brunswick had Maine's UI system. Thus, UI policy differences explain about two thirds $((20.8-11.4) /(20.8-6.1)$ of this differential. For women in 1990, 13.8 percent worked less than half year in Northern Maine, compared to 26.2 percent in New Brunswick. Similar calculations imply that UI policy differences can account for essentially all of this difference.

As noted, it is striking that the effects of UI on weeks-worked distributions described above are observed at the level of the entire labor force (not just for the highly restricted samples often analyzed in income-support studies, such as single mothers, former welfare recipients, or workers who have just initiated an unemployment spell). That said, it is useful to investigate whether a sample of less-skilled workers would be more responsive to UI incentives than the population as a whole, particularly since UI replacement rates are higher among the less-skilled. To that end, we replicated the entire analysis underlying Table 10 for a sample of workers with a high-school degree or less. The results are shown in Table 11.8 Compared to all men, there is a larger inter-regional difference in the 1990 share working part-year (under 40 weeks) among the less-educated at $(100-82=) 18$ percent in Northern Maine versus $(100-66=) 34$ percent in New 
Brunswick. According to Table 11, UI policy explains 80.3-66.3=14 percentage points of this 16 point difference. The results are even more dramatic for the share of men working less than half the year. In 1990 more than a quarter of New Brunswick's men $(5.5+20.2=25.7$ percent $)$ fell into this category, compared to 10.3 percent in Northern Maine. Imposing Maine’s UI system on New Brunswick reduces this 25.7 percent to 11.4 percent. The model therefore attributes almost the entire international gap in 1990 to the UI policy differential.

For less-educated women, Table 11 shows an interregional gap in the 1990 incidence of partyear work (under 40 weeks) equal to $68.9-60.3=8.6$ percentage points. Under Maine's rules women in New Brunswick would have worked part-year 72.1-60.3 $=11.8$ percentage points less frequently. The interregional gap in the share working half-year or less is 11.3 percentage points, essentially all of which is again attributed to UI policy differences. In contrast to men, these predicted UI effects for less-educated women are not unambiguously greater than those for the entire female labor force. Perhaps because of women's lower wages overall, and perhaps because of a greater desire to spend time with their children, better- educated women appear to be just as likely to respond to the UI program as less-educated women.

\section{Conclusions}

In 1990, six percent of 25-59-year-old men in Maine's Northern Counties worked fewer than 26 weeks. Just across the Saint Croix River in New Brunswick, that figure was more than three times as high, at 20 percent. Our results suggest that a large share of this difference can be explained by the much more generous Canadian Unemployment Insurance system. These results are derived from a unique and dramatic natural income-support experiment spanning 50 years, during which we see a close link between these jurisdictions' relative weeks-worked

\footnotetext{
${ }^{38}$ Predicted distributions correspond very closely to the actual ones; for brevity, we report predictions only.
} 
distributions and New Brunswick's UI policy changes. Further, the fact that our very parsimonious model accurately predicts which particular weeks-worked categories became relatively more common after New Brunswick's 1971 UI reforms considerably strengthens the case for a causal role of UI policy.

In more detail, we identify large effects of UI program generosity on the likelihood of working a relatively small number of weeks per year - for example, 1 to 13 weeks or 14 to 26 weeks. For both men and women, a ten percent UI-induced increase in the income associated with working less than half-year is estimated to raise the number of persons working less than half year by about the same ratio. These large UI-induced changes in the incidence of part-year work in turn suggest large elasticities of program participation - and therefore program expenditures - with respect to program generosity. For instance, raising the income associated with part-year work by 10 percent raises the number of men receiving UI benefits by 8 percent, and the number of UI benefit weeks paid to men by 7.4 percent. Needless to say, such responses should play important roles in the cost-benefit analysis of any income support policy.

The approach taken in this paper differs from most existing studies of the labor market effects of income support programs which (for good reason) restrict their attention to the shortrun effects of small policy changes on the labor supply of specific at-risk groups (e.g. former welfare recipients; workers who have just become unemployed). In contrast, we evaluate the long-run impact of a very generous unemployment insurance program on the amount of work performed by a region's entire workforce. Clearly, because they allow both workers and firms to make larger adjustments on a greater number of margins, both the size and permanence of the UI policy changes studied here may help account for the relatively large responses estimated here. Among the margins of adjustment that are likely to play a larger role in the long run are 
education decisions, occupational choices, fertility decisions, migration (workers with high tastes for leisure may be induced to remain in New Brunswick by UI policy), learning effects (it takes time and/or experience to understand the workings of the UI system), and the development of informal institutions (such as relabelling of separations and the job-sharing example discussed in Section 4) to take most effective advantage of the UI program.

Finally, two additional factors may contribute to the large estimated responses in this paper. One is social effects: the large UI participation rates generated by the Canadian program may themselves help disseminate knowledge about how the program works, and may effectively eliminate any stigma associated with benefit receipt. We do not attempt to distinguish such induced social effects from 'first-order' program effects in this paper; we simply note that any such social multipliers may help explain the size of our estimates. ${ }^{40}$ The second possible contributing factor to our large estimated effects is the pre-existing pattern of seasonal work in both these jurisdictions. Clearly, to the extent that a program's main effect is to preserve a preexisting way of life, any adjustment costs will work in favor of, rather than against, large program effects. That said, our estimates attribute large increases in women's part-year work to New Brunswick's UI system. Importantly, these effects are observed in sectors such as services (which accounts for half of female employment), not just in 'inherently' seasonal activities such as primary industries. Thus, for women, it appears that UI has not just preserved an existing lifestyle, but actually created a new one based on chronic seasonal unemployment.

\footnotetext{
${ }^{39}$ Of course, some of these margins (in particular education decisions, occupational choices, and fertility decisions) are at least partially controlled for in our estimation procedure. To the extent they are held constant in our analysis, even the large estimates in this paper are likely to understate the overall magnitude of responses to UI.

${ }^{40}$ See for example Bertrand et al. (2000) for a recent study of social effects on income support program participation
} 


\section{References}

Alesina, A., E. Glaeser, and B. Sacerdote. 2005. "Work and Leisure in the U.S. and Europe: Why so Different?" NBER Macroeconomics Annua.

Anderson, Patricia M. and Bruce D. Meyer. 1997. "Unemployment Insurance Take-up Rates and the After-tax Value of Benefits" Quarterly Journal of Economics, Volume 112, Number 3, pp. 913-37.

Ashenfelter, Orley and David E. Card. 1986. "Why have Unemployment Rates in Canada and the United States Diverged?” Economica, Volume 53, pp.171-95

Baker, Michael and Samuel A. Rea. 1998. "Employment Spells and Unemployment Insurance Eligibility Requirements" Review of Economics and Statistics, Volume 80, Number 1, pp.80-94.

Bertrand, Marianne, Luttmer, Erzo, and Sendhil Mullainathan. 2000. "Network Effects and Welfare Cultures” Quarterly Journal of Economics, Volume 115, Number 3, pp. 101955.

Blank, Rebecca M., and David E. Card. 1991. "Recent Trends in Insured and Uninsured Unemployment: Is There an Explanation?” Quarterly Journal of Economics, Volume 106, Number 4, pp. 1157-89.

Borjas, George. 1980. "The Relationship between Wages and Weekly Hours of Work: The Role of Division Bias" Journal of Human Resources, Volume 15, Number 3, pp. 409-423.

Commission of Inquiry on Unemployment Insurance. 1986. Report. Ottawa: Minister of Supply and Services.

Dingledine, Gary. 1981. A chronology of response: The evolution of unemployment insurance from 1940 to 1980. Ottawa: Minister of Supply and Services.

Green, David A. and W. Craig Riddell. 1997. 'Qualifying for Unemployment Insurance: An Empirical Analysis” Economic Journal, Volume 107, Number 440, pp. 67-84.

Green, David A. and Timothy Sargent. 1998. "Unemployment Insurance and Job Durations: Seasonal and Non-seasonal Jobs" Canadian Journal of Economics, Volume 31, Number 2, pp. 247-78.

Hamermesh, Daniel S. 2002. "International Labor Economics” Journal of Labor Economics, Volume 20, Number 4, pp. 709-32.

Harris, Michael. 1998. Lament for an Ocean: The Collapse of the Atlantic Cod Fishery: A True Crime Story. Toronto: McClelland \& Stewart. 
Human Resources Development Canada. 2005. "Unemployment Insurance in Canada" http://www.hrdc-drhc.ca/ae-ei/hist/chapter4.shtml

Kuhn, Peter and Arthur Sweetman. 1998. "Unemployment Insurance and Quits in Canada" Canadian Journal of Economics, Volume 31, Number 3, pp. 549-72.

Krueger, Alan and Bruce Meyer. 2002. "Labor Supply Effects of Social Insurance”, in A. Auerbach and M. Feldstein, eds. Handbook of Public Economics, Volume 4. Amsterdam: Elsevier, pp. 2327-2392.

MacLeod, W. B. and Thomas Lemieux. 2001. 'Supply Side Hysteresis: The Case of the Canadian Unemployment System” Journal of Public Economics, Volume 78, Number 2, pp.139-170.

Murray, Charles A. 1994. Losing ground: American social policy, 1950-1980. New York: Basic Books.

Prescott, E. C. 2004. "Why do Americans Work So Much More than Europeans?" Federal Reserve Bank of Minneapolis Quarterly Review, Volume 28, Number 1. 


\section{Table 1}

Government Transfer Payments in Maine and New Brunswick, 1990

\section{A. All Persons:}

\begin{tabular}{|l|c|c|}
\hline & Men & Women \\
\hline 1. Fraction receiving unemployment insurance \\
\hline New Brunswick & .228 & .182 \\
\hline Maine & .056 & .031 \\
\hline 2. Fraction receiving other transfer payments & \\
\hline New Brunswick & .117 & .117 \\
\hline Maine & .062 & .082 \\
\hline
\end{tabular}

\section{B. Workers ${ }^{2}$ Only:}

\begin{tabular}{|l|c|c|}
\hline & Men & Women \\
\hline 1. Fraction receiving unemployment insurance \\
\hline New Brunswick & .295 & .297 \\
\hline Maine & .057 & .033 \\
\hline 2. Fraction receiving other transfer payments & \\
\hline New Brunswick & .054 & \\
\hline Maine & .039 & .058 \\
\hline
\end{tabular}

1. In Maine, "other transfer payments" include public assistance, veterans' benefits and food stamps only. In New Brunswick, it includes social assistance, veterans pensions, workers compensation, disability benefits, mothers' allowances, Canada manpower training and mobility allowances, and provincial income supplements.

2. 'Workers' includes all individuals with positive weeks worked in the reference calendar year.

Age is restricted to 25 to 59 years.

Sources: Authors' calculations from 1991 Census of Canada and March 1990 Current Population Survey. CPS figures are weighted by CPS final weight. 
Table 2

Estimated total annual income from part-year work, as a fraction of income earned from full-year work, Cell-level census data 1940-91

\begin{tabular}{|c|c|c|c|c|c|c|}
\hline & 1940 & 1950 & 1960 & 1970 & 1980 & 1990 \\
\hline & \multicolumn{6}{|c|}{ Part-year $=20$ weeks } \\
\hline \multicolumn{7}{|l|}{ MEN: } \\
\hline New Brunswick & .385 & .441 & .580 & .551 & .680 & .713 \\
\hline Maine & .454 & .456 & .479 & .495 & .509 & .509 \\
\hline \multicolumn{7}{|l|}{ WOMEN: } \\
\hline New Brunswick & .385 & .455 & .614 & .579 & .731 & .731 \\
\hline \multirow[t]{2}{*}{ Maine } & .474 & .478 & .511 & .509 & .513 & .513 \\
\hline & \multicolumn{6}{|c|}{ Part-year $=30$ weeks } \\
\hline \multicolumn{7}{|l|}{ MEN: } \\
\hline New Brunswick & .577 & .688 & .761 & .734 & .774 & .796 \\
\hline Maine & .673 & .672 & .680 & .702 & .718 & .720 \\
\hline \multicolumn{7}{|l|}{ WOMEN: } \\
\hline New Brunswick & .577 & .716 & .793 & .760 & .808 & .808 \\
\hline Maine & .697 & .693 & .709 & .763 & .769 & .769 \\
\hline
\end{tabular}

NOTES: Standard errors are in parentheses. All means are based on 9 industries for men and 6 industries for women, and are weighted by the underlying number of observations. The sources are the 1940/50/60/70/80/90 U.S. censuses for Maine and the 1941/51/61/71/81/91 Canadian censuses for New Brunswick. See text for discussion of the computation of the relative income variable, and further discussion of the data.

Table 3

Percent of workers working part year, Census data 1940-91

\begin{tabular}{|l|c|c|c|c|c|c|}
\hline & $\mathbf{1 9 4 0}$ & $\mathbf{1 9 5 0}$ & $\mathbf{1 9 6 0}$ & $\mathbf{1 9 7 0}$ & $\mathbf{1 9 8 0}$ & $\mathbf{1 9 9 0}$ \\
\hline & & & & & & \\
\hline MEN: & & & & & & \\
\hline New Brunswick & .36 & .27 & .33 & .34 & .35 & .36 \\
\hline Maine & .31 & .25 & .25 & .24 & .24 & .22 \\
\hline & & & & & & \\
\hline WOMEN: & & & & & & \\
\hline New Brunswick & .20 & .14 & .31 & .44 & .47 & .40 \\
\hline Maine & .37 & .37 & .50 & .48 & .40 & .31 \\
\hline
\end{tabular}

NOTES: Part-year work is defined as working less than 40 weeks. The sources are the 1940/50/60/70/80/90 U.S. censuses for Maine and the 1941/51/61/71/81/91 Canadian censuses for New Brunswick. See text for further discussion of the computation of part-year work, and discussion of the data. 
Table 4

Regression estimates of the incidence of part year work, Cell data 1940-91

\begin{tabular}{|c|c|c|c|c|}
\hline \multirow[t]{2}{*}{ Variable } & \multicolumn{2}{|c|}{ 20-week UI parameters } & \multicolumn{2}{|c|}{ 30-week UI parameters } \\
\hline & MEN & WOMEN & MEN & WOMEN \\
\hline & (1) & (2) & (3) & (4) \\
\hline Relative income & $\begin{array}{c}.172 \\
(2.27)\end{array}$ & $\begin{array}{c}.476 \\
(5.99)\end{array}$ & $\begin{array}{c}.221 \\
(1.66)\end{array}$ & $\begin{array}{c}.316 \\
(1.51)\end{array}$ \\
\hline New Brunswick & $\begin{array}{c}.042 \\
(2.18)\end{array}$ & $\begin{array}{l}-.135 \\
(5.45)\end{array}$ & $\begin{array}{c}.055 \\
(3.34)\end{array}$ & $\begin{array}{c}-.076 \\
(2.73)\end{array}$ \\
\hline Agriculture & $\begin{array}{c}.277 \\
(7.91)\end{array}$ & & $\begin{array}{c}.279 \\
(7.48)\end{array}$ & \\
\hline Construction & $\begin{array}{c}.224 \\
(6.35)\end{array}$ & & $\begin{array}{c}.223 \\
(6.11)\end{array}$ & \\
\hline Finance & $\begin{array}{l}-.111 \\
(5.21)\end{array}$ & $\begin{array}{l}-.204 \\
(6.03)\end{array}$ & $\begin{array}{c}-.107 \\
(4.68)\end{array}$ & $\begin{array}{l}-.212 \\
(5.26)\end{array}$ \\
\hline Government & $\begin{array}{l}-.071 \\
(2.61)\end{array}$ & $\begin{array}{l}-.044 \\
(0.89)\end{array}$ & $\begin{array}{l}-.070 \\
(2.37)\end{array}$ & $\begin{array}{l}-.063 \\
(1.16)\end{array}$ \\
\hline Primary & $\begin{array}{c}.335 \\
(10.87)\end{array}$ & & $\begin{array}{c}.333 \\
(10.86)\end{array}$ & \\
\hline Services & $\begin{array}{c}.031 \\
(0.97)\end{array}$ & $\begin{array}{l}-.006 \\
(0.18)\end{array}$ & $\begin{array}{c}.030 \\
(0.91)\end{array}$ & $\begin{array}{l}-.016 \\
(0.35)\end{array}$ \\
\hline Trade & $\begin{array}{l}-.010 \\
(0.43)\end{array}$ & $\begin{array}{l}-.011 \\
(0.30)\end{array}$ & $\begin{array}{l}-.013 \\
(0.59)\end{array}$ & $\begin{array}{l}-.018 \\
(0.44)\end{array}$ \\
\hline Transportation & $\begin{array}{l}-.034 \\
(1.72)\end{array}$ & $\begin{array}{c}-.143 \\
(3.72)\end{array}$ & $\begin{array}{c}-.034 \\
(1.77)\end{array}$ & $\begin{array}{l}-.148 \\
(3.40)\end{array}$ \\
\hline 1950 & $\begin{array}{c}-.071 \\
(2.57)\end{array}$ & $\begin{array}{c}-.065 \\
(1.55)\end{array}$ & $\begin{array}{l}-.079 \\
(2.64)\end{array}$ & $\begin{array}{c}-.057 \\
(0.98)\end{array}$ \\
\hline 1960 & $\begin{array}{l}-.044 \\
(1.36)\end{array}$ & $\begin{array}{c}.003 \\
(0.05)\end{array}$ & $\begin{array}{l}-.036 \\
(1.10)\end{array}$ & $\begin{array}{c}.078 \\
(1.16)\end{array}$ \\
\hline 1970 & $\begin{array}{l}-.035 \\
(1.15)\end{array}$ & $\begin{array}{c}.071 \\
(2.10)\end{array}$ & $\begin{array}{l}-.028 \\
(0.90)\end{array}$ & $\begin{array}{c}.127 \\
(2.29)\end{array}$ \\
\hline 1980 & $\begin{array}{l}-.058 \\
(1.56)\end{array}$ & $\begin{array}{l}-.008 \\
(0.19)\end{array}$ & $\begin{array}{c}-.039 \\
(1.12)\end{array}$ & $\begin{array}{c}.096 \\
(1.42)\end{array}$ \\
\hline 1990 & $\begin{array}{c}-.068 \\
(1.71)\end{array}$ & $\begin{array}{c}-.089 \\
(2.19)\end{array}$ & $\begin{array}{c}-.048 \\
(1.27)\end{array}$ & $\begin{array}{c}.015 \\
(0.21)\end{array}$ \\
\hline $\mathrm{R}^{2}$ & .785 & .712 & .779 & .581 \\
\hline $\mathrm{N}$ & 108 & 72 & 108 & 72 \\
\hline
\end{tabular}

NOTES: Coefficients are derived from a WLS regression of the fraction of workers working fewer than 40 weeks per year on the independent variables shown. Marginal effects -i.e. the predicted change in the part-year share at the means of the data-are reported. Robust $t$-statistics are in parentheses (in absolute value). The 'relative income' variable is defined as the log of (part-year income / full-year income). Manufacturing is the omitted industry group and 1940 is the omitted year. All regressions include a constant term, and are weighted by annual industry shares in employment. 
Table 5

Descriptive Statistics: Men

\begin{tabular}{|c|c|c|c|c|c|c|c|c|c|}
\hline \multirow[t]{2}{*}{ Variable } & \multicolumn{3}{|c|}{ New Brunswick } & \multicolumn{3}{|c|}{ Maine-Northern Counties } & \multicolumn{3}{|c|}{ Maine } \\
\hline & 1970 & 1980 & 1990 & 1970 & 1980 & 1990 & 1970 & 1980 & 1990 \\
\hline Age & $\begin{array}{l}40.96 \\
(.362)\end{array}$ & $\begin{array}{l}38.24 \\
(.214)\end{array}$ & $\begin{array}{l}39.22 \\
(.149)\end{array}$ & $\begin{array}{l}41.09 \\
(.462)\end{array}$ & $\begin{array}{l}39.23 \\
(.187)\end{array}$ & $\begin{array}{l}38.92 \\
(.154)\end{array}$ & $\begin{array}{l}40.97 \\
(.258)\end{array}$ & $\begin{array}{l}39.15 \\
(.107)\end{array}$ & $\begin{array}{l}38.99 \\
(.089)\end{array}$ \\
\hline Agriculture & $\begin{array}{l}.010 \\
(.003)\end{array}$ & $\begin{array}{l}.009 \\
(.002)\end{array}$ & $\begin{array}{l}.016 \\
(.002)\end{array}$ & $\begin{array}{l}.031 \\
(.009)\end{array}$ & $\begin{array}{l}.031 \\
(.003)\end{array}$ & $\begin{array}{l}.032 \\
(.003)\end{array}$ & $\begin{array}{l}.029 \\
(.004)\end{array}$ & $\begin{array}{l}.019 \\
(.001)\end{array}$ & $\begin{array}{c}.020 \\
(.001)\end{array}$ \\
\hline Primary & $\begin{array}{c}.079 \\
(.009)\end{array}$ & $\begin{array}{c}.085 \\
(.006)\end{array}$ & $\begin{array}{c}.081 \\
(.004)\end{array}$ & $\begin{array}{c}.044 \\
(.009)\end{array}$ & $\begin{array}{c}.037 \\
(.003)\end{array}$ & $\begin{array}{c}.043 \\
(.003)\end{array}$ & $\begin{array}{c}.022 \\
(.004)\end{array}$ & $\begin{array}{c}.023 \\
(.002)\end{array}$ & $\begin{array}{c}.029 \\
(.002)\end{array}$ \\
\hline Construction & $\begin{array}{c}.084 \\
(.009)\end{array}$ & $\begin{array}{c}.115 \\
(.007)\end{array}$ & $\begin{array}{l}.115 \\
(.005)\end{array}$ & $\begin{array}{l}.108 \\
(.014)\end{array}$ & $\begin{array}{c}.091 \\
(.005)\end{array}$ & $\begin{array}{c}.120 \\
(.005)\end{array}$ & $\begin{array}{c}.091 \\
(.007)\end{array}$ & $\begin{array}{c}.091 \\
(.003)\end{array}$ & $\begin{array}{l}.126 \\
(.003)\end{array}$ \\
\hline Transportation & $\begin{array}{c}.171 \\
(.013)\end{array}$ & $\begin{array}{c}.156 \\
(.008)\end{array}$ & $\begin{array}{c}.133 \\
(.006)\end{array}$ & $\begin{array}{c}.101 \\
(.014)\end{array}$ & $\begin{array}{c}.096 \\
(.005)\end{array}$ & $\begin{array}{c}.070 \\
(.004)\end{array}$ & $\begin{array}{c}.082 \\
(.007)\end{array}$ & $\begin{array}{c}.084 \\
(.003)\end{array}$ & $\begin{array}{c}.073 \\
(.003)\end{array}$ \\
\hline Trade & $\begin{array}{l}.126 \\
(.011)\end{array}$ & $\begin{array}{c}.126 \\
(.007)\end{array}$ & $\begin{array}{l}.127 \\
(.005)\end{array}$ & $\begin{array}{l}.142 \\
(.016)\end{array}$ & $\begin{array}{c}.132 \\
(.006)\end{array}$ & $\begin{array}{c}.152 \\
(.006)\end{array}$ & $\begin{array}{l}.163 \\
(.010)\end{array}$ & $\begin{array}{c}.143 \\
(.004)\end{array}$ & $\begin{array}{l}.157 \\
(.004)\end{array}$ \\
\hline Finance & $\begin{array}{c}.018 \\
(.005)\end{array}$ & $\begin{array}{c}.025 \\
(.003)\end{array}$ & $\begin{array}{c}.029 \\
(.003)\end{array}$ & $\begin{array}{c}.021 \\
(.007)\end{array}$ & $\begin{array}{c}.023 \\
(.003)\end{array}$ & $\begin{array}{c}.015 \\
(.002)\end{array}$ & $\begin{array}{c}.025 \\
(.004)\end{array}$ & $\begin{array}{c}.029 \\
(.002)\end{array}$ & $\begin{array}{c}.025 \\
(.001) \\
\end{array}$ \\
\hline Services & $\begin{array}{c}.134 \\
(.012)\end{array}$ & $\begin{array}{c}.155 \\
(.008)\end{array}$ & $\begin{array}{c}.174 \\
(.006)\end{array}$ & $\begin{array}{l}.145 \\
(.016)\end{array}$ & $\begin{array}{c}.170 \\
(.007)\end{array}$ & $\begin{array}{c}.178 \\
(.006)\end{array}$ & $\begin{array}{c}.129 \\
(.009)\end{array}$ & $\begin{array}{l}.168 \\
(.004)\end{array}$ & $\begin{array}{l}.183 \\
(.004)\end{array}$ \\
\hline Manufacturing & $\begin{array}{c}.209 \\
(.014)\end{array}$ & $\begin{array}{c}.204 \\
(.009)\end{array}$ & $\begin{array}{c}.197 \\
(.006)\end{array}$ & $\begin{array}{c}.296 \\
(.021)\end{array}$ & $\begin{array}{c}.298 \\
(.008)\end{array}$ & $\begin{array}{c}.253 \\
(.007)\end{array}$ & $\begin{array}{c}.369 \\
(.012)\end{array}$ & $\begin{array}{c}.334 \\
(.005)\end{array}$ & $\begin{array}{c}.284 \\
(.004)\end{array}$ \\
\hline Public & $\begin{array}{l}.167 \\
(.013)\end{array}$ & $\begin{array}{l}.126 \\
(.007)\end{array}$ & $\begin{array}{c}.127 \\
(.005)\end{array}$ & $\begin{array}{l}.108 \\
(.014)\end{array}$ & $\begin{array}{c}.122 \\
(.006)\end{array}$ & $\begin{array}{l}.137 \\
(.006)\end{array}$ & $\begin{array}{c}.089 \\
(.007)\end{array}$ & $\begin{array}{l}.109 \\
(.003)\end{array}$ & $\begin{array}{c}.102 \\
(.003) \\
\end{array}$ \\
\hline Married & $\begin{array}{c}.856 \\
(.012)\end{array}$ & $\begin{array}{c}.828 \\
(.008)\end{array}$ & $\begin{array}{c}.810 \\
(.006)\end{array}$ & $\begin{array}{c}.902 \\
(.014)\end{array}$ & $\begin{array}{c}.812 \\
(.007)\end{array}$ & $\begin{array}{c}.751 \\
(.007)\end{array}$ & $\begin{array}{c}.863 \\
(.009)\end{array}$ & $\begin{array}{c}.804 \\
(.004)\end{array}$ & $\begin{array}{c}.742 \\
(.004)\end{array}$ \\
\hline Children & $\begin{array}{c}.710 \\
(.016)\end{array}$ & $\begin{array}{c}.714 \\
(.009)\end{array}$ & $\begin{array}{c}.692 \\
(.007)\end{array}$ & $\begin{array}{c}.699 \\
(.021)\end{array}$ & $\begin{array}{c}.630 \\
(.009)\end{array}$ & $\begin{array}{c}.564 \\
(.008)\end{array}$ & $\begin{array}{c}.686 \\
(.012)\end{array}$ & $\begin{array}{c}.620 \\
(.005)\end{array}$ & $\begin{array}{c}.562 \\
(.005) \\
\end{array}$ \\
\hline Attending school & $\begin{array}{c}.056 \\
(.008)\end{array}$ & $\begin{array}{c}.069 \\
(.006)\end{array}$ & $\begin{array}{c}.072 \\
(.004)\end{array}$ & $\begin{array}{c}.009 \\
(.004)\end{array}$ & $\begin{array}{c}.033 \\
(.003) \\
\end{array}$ & $\begin{array}{c}.058 \\
(.004)\end{array}$ & $\begin{array}{c}.026 \\
(.004)\end{array}$ & $\begin{array}{c}.038 \\
(.002)\end{array}$ & $\begin{array}{c}.052 \\
(.002) \\
\end{array}$ \\
\hline $\begin{array}{l}\text { High school or } \\
\text { less }\end{array}$ & $\begin{array}{c}.882 \\
(.011)\end{array}$ & $\begin{array}{l}.575 \\
(.011)\end{array}$ & $\begin{array}{l}.524 \\
(.008)\end{array}$ & $\begin{array}{l}.835 \\
(.017)\end{array}$ & $\begin{array}{l}.670 \\
(.009)\end{array}$ & $\begin{array}{l}.584 \\
(.008)\end{array}$ & $\begin{array}{l}.799 \\
(.010)\end{array}$ & $\begin{array}{l}.642 \\
(.005)\end{array}$ & $\begin{array}{l}.550 \\
(.005)\end{array}$ \\
\hline $\begin{array}{l}\text { Some post- } \\
\text { secondary }\end{array}$ & $\begin{array}{c}.049 \\
(.008)\end{array}$ & $\begin{array}{l}.311 \\
(.010)\end{array}$ & $\begin{array}{c}.340 \\
(.008)\end{array}$ & $\begin{array}{c}.086 \\
(.013)\end{array}$ & $\begin{array}{l}.156 \\
(.007)\end{array}$ & $\begin{array}{l}.250 \\
(.007)\end{array}$ & $\begin{array}{l}.100 \\
(.008)\end{array}$ & $\begin{array}{l}.172 \\
(.004)\end{array}$ & $\begin{array}{c}.253 \\
(.004)\end{array}$ \\
\hline Four-year degree & $\begin{array}{l}.069 \\
(.009)\end{array}$ & $\begin{array}{l}.114 \\
(.007) \\
\end{array}$ & $\begin{array}{l}.135 \\
(.006)\end{array}$ & $\begin{array}{l}.077 \\
(.012)\end{array}$ & $\begin{array}{l}.174 \\
(.007)\end{array}$ & $\begin{array}{l}.166 \\
(.006) \\
\end{array}$ & $\begin{array}{l}.101 \\
(.008)\end{array}$ & $\begin{array}{l}.186 \\
(.004)\end{array}$ & $\begin{array}{l}.198 \\
(.004)\end{array}$ \\
\hline $\begin{array}{l}\text { Part-time (under } \\
30 \text { hours/week) }\end{array}$ & $\begin{array}{l}.031 \\
(.006)\end{array}$ & $\begin{array}{l}.061 \\
(.005)\end{array}$ & $\begin{array}{l}.043 \\
(.003)\end{array}$ & $\begin{array}{l}.032 \\
(.008)\end{array}$ & $\begin{array}{c}.023 \\
(.003)\end{array}$ & $\begin{array}{c}.029 \\
(.003)\end{array}$ & $\begin{array}{l}.023 \\
(.004)\end{array}$ & $\begin{array}{l}.023 \\
(.002)\end{array}$ & $\begin{array}{r}.024 \\
(.001) \\
\end{array}$ \\
\hline Sample size & 832 & 2111 & 3811 & 462 & 2922 & 3681 & 1499 & 8891 & 10813 \\
\hline
\end{tabular}

NOTES: Standard errors are in parentheses. The sample is restricted to individuals of age 25 to 59 , with at least one week of work in the calendar year preceding the Census. 
Table 6

Descriptive Statistics: Women

\begin{tabular}{|c|c|c|c|c|c|c|c|c|c|}
\hline \multirow[t]{2}{*}{ Variable } & \multicolumn{3}{|c|}{ New Brunswick } & \multicolumn{3}{|c|}{ Maine-Northern Counties } & \multicolumn{3}{|c|}{ Maine } \\
\hline & 1970 & 1980 & 1990 & 1970 & 1980 & 1990 & 1970 & 1980 & 1990 \\
\hline Age & $\begin{array}{l}40.48 \\
(.497)\end{array}$ & $\begin{array}{l}37.59 \\
(.263)\end{array}$ & $\begin{array}{l}38.46 \\
(.160)\end{array}$ & $\begin{array}{l}42.41 \\
(.573)\end{array}$ & $\begin{array}{l}39.27 \\
(.214)\end{array}$ & $\begin{array}{l}39.15 \\
(.162)\end{array}$ & $\begin{array}{l}42.05 \\
(.312)\end{array}$ & $\begin{array}{l}39.30 \\
(.122)\end{array}$ & $\begin{array}{l}38.97 \\
(.090)\end{array}$ \\
\hline Agriculture & $\begin{array}{c}.007 \\
(.004)\end{array}$ & $\begin{array}{c}.010 \\
(.003)\end{array}$ & $\begin{array}{c}.018 \\
(.002)\end{array}$ & $\begin{array}{c}.020 \\
(.008)\end{array}$ & $\begin{array}{c}.021 \\
(.003)\end{array}$ & $\begin{array}{c}.020 \\
(.002)\end{array}$ & $\begin{array}{c}.021 \\
(.005)\end{array}$ & $\begin{array}{c}.012 \\
(.001)\end{array}$ & $\begin{array}{c}.013 \\
(.001)\end{array}$ \\
\hline Primary & $\begin{array}{l}.005 \\
(.003)\end{array}$ & $\begin{array}{c}.017 \\
(.004)\end{array}$ & $\begin{array}{c}.014 \\
(.002)\end{array}$ & $\begin{array}{c}.000 \\
(.000)\end{array}$ & $\begin{array}{c}.007 \\
(.002)\end{array}$ & $\begin{array}{c}.007 \\
(.002)\end{array}$ & $\begin{array}{c}.004 \\
(.002)\end{array}$ & $\begin{array}{c}.003 \\
(.001)\end{array}$ & $\begin{array}{c}.004 \\
(.001) \\
\end{array}$ \\
\hline Construction & $\begin{array}{c}.007 \\
(.004)\end{array}$ & $\begin{array}{c}.017 \\
(.004)\end{array}$ & $\begin{array}{c}.011 \\
(.002)\end{array}$ & $\begin{array}{c}.007 \\
(.005)\end{array}$ & $\begin{array}{c}.007 \\
(.002)\end{array}$ & $\begin{array}{c}.010 \\
(.002)\end{array}$ & $\begin{array}{l}.009 \\
(.003)\end{array}$ & $\begin{array}{c}.006 \\
(.001)\end{array}$ & $\begin{array}{c}.013 \\
(.001) \\
\end{array}$ \\
\hline Transportation & $\begin{array}{c}.043 \\
(.010)\end{array}$ & $\begin{array}{c}.038 \\
(.005)\end{array}$ & $\begin{array}{c}.039 \\
(.003)\end{array}$ & $\begin{array}{c}.020 \\
(.008)\end{array}$ & $\begin{array}{c}.022 \\
(.003)\end{array}$ & $\begin{array}{c}.023 \\
(.003)\end{array}$ & $\begin{array}{c}.023 \\
(.005)\end{array}$ & $\begin{array}{c}.026 \\
(.002)\end{array}$ & $\begin{array}{c}.026 \\
(.002)\end{array}$ \\
\hline Trade & $\begin{array}{c}.204 \\
(.020)\end{array}$ & $\begin{array}{c}.158 \\
(.010)\end{array}$ & $\begin{array}{c}.157 \\
(.006)\end{array}$ & $\begin{array}{c}.215 \\
(.024)\end{array}$ & $\begin{array}{c}.170 \\
(.008)\end{array}$ & $\begin{array}{c}.201 \\
(.007)\end{array}$ & $\begin{array}{c}.207 \\
(.013)\end{array}$ & $\begin{array}{c}.166 \\
(.004)\end{array}$ & $\begin{array}{c}.197 \\
(.004)\end{array}$ \\
\hline Finance & $\begin{array}{c}.048 \\
(.011)\end{array}$ & $\begin{array}{c}.064 \\
(.007)\end{array}$ & $\begin{array}{l}.066 \\
(.004)\end{array}$ & $\begin{array}{c}.027 \\
(.009)\end{array}$ & $\begin{array}{c}.047 \\
(.004)\end{array}$ & $\begin{array}{c}.052 \\
(.004)\end{array}$ & $\begin{array}{l}.050 \\
(.007)\end{array}$ & $\begin{array}{c}.060 \\
(.003)\end{array}$ & $\begin{array}{r}.070 \\
(.003) \\
\end{array}$ \\
\hline Services & $\begin{array}{c}.468 \\
(.024)\end{array}$ & $\begin{array}{c}.487 \\
(.013)\end{array}$ & $\begin{array}{c}.489 \\
(.009)\end{array}$ & $\begin{array}{c}.414 \\
(.029)\end{array}$ & $\begin{array}{c}.448 \\
(.011)\end{array}$ & $\begin{array}{c}.487 \\
(.009)\end{array}$ & $\begin{array}{c}.323 \\
(.015)\end{array}$ & $\begin{array}{c}.410 \\
(.006)\end{array}$ & $\begin{array}{c}.463 \\
(.005) \\
\end{array}$ \\
\hline Manufacturing & $\begin{array}{l}.127 \\
(.016)\end{array}$ & $\begin{array}{c}.132 \\
(.009)\end{array}$ & $\begin{array}{c}.096 \\
(.005)\end{array}$ & $\begin{array}{c}.269 \\
(.026)\end{array}$ & $\begin{array}{c}.210 \\
(.009)\end{array}$ & $\begin{array}{c}.128 \\
(.006)\end{array}$ & $\begin{array}{l}.323 \\
(.015)\end{array}$ & $\begin{array}{l}.250 \\
(.005)\end{array}$ & $\begin{array}{c}.154 \\
(.004) \\
\end{array}$ \\
\hline Public & $\begin{array}{c}.089 \\
(.014)\end{array}$ & $\begin{array}{c}.077 \\
(.007)\end{array}$ & $\begin{array}{c}.108 \\
(.006)\end{array}$ & $\begin{array}{c}.027 \\
(.009)\end{array}$ & $\begin{array}{c}.069 \\
(.005)\end{array}$ & $\begin{array}{c}.072 \\
(.005)\end{array}$ & $\begin{array}{c}.040 \\
(.006)\end{array}$ & $\begin{array}{c}.067 \\
(.003)\end{array}$ & $\begin{array}{c}.061 \\
(.002) \\
\end{array}$ \\
\hline Married & $\begin{array}{c}.731 \\
(.022)\end{array}$ & $\begin{array}{c}.770 \\
(.011)\end{array}$ & $\begin{array}{c}.783 \\
(.007)\end{array}$ & $\begin{array}{c}.778 \\
(.024)\end{array}$ & $\begin{array}{c}.743 \\
(.009)\end{array}$ & $\begin{array}{c}.737 \\
(.008)\end{array}$ & $\begin{array}{c}.767 \\
(.013)\end{array}$ & $\begin{array}{c}.727 \\
(.005)\end{array}$ & $\begin{array}{c}.716 \\
(.004)\end{array}$ \\
\hline Children & $\begin{array}{c}.728 \\
(.022)\end{array}$ & $\begin{array}{c}.625 \\
(.013)\end{array}$ & $\begin{array}{c}.691 \\
(.008)\end{array}$ & $\begin{array}{c}.596 \\
(.029)\end{array}$ & $\begin{array}{c}.638 \\
(.010)\end{array}$ & $\begin{array}{c}.622 \\
(.009)\end{array}$ & $\begin{array}{l}.626 \\
(.015)\end{array}$ & $\begin{array}{c}.631 \\
(.006)\end{array}$ & $\begin{array}{r}.609 \\
(.005) \\
\end{array}$ \\
\hline In school & $\begin{array}{c}.058 \\
(.011)\end{array}$ & $\begin{array}{c}.077 \\
(.007)\end{array}$ & $\begin{array}{c}.078 \\
(.005)\end{array}$ & $\begin{array}{c}.020 \\
(.008)\end{array}$ & $\begin{array}{c}.044 \\
(.004)\end{array}$ & $\begin{array}{c}.086 \\
(.005)\end{array}$ & $\begin{array}{c}.019 \\
(.004)\end{array}$ & $\begin{array}{c}.044 \\
(.002)\end{array}$ & $\begin{array}{c}.078 \\
(.003) \\
\end{array}$ \\
\hline $\begin{array}{l}\text { High school or } \\
\text { less }\end{array}$ & $\begin{array}{l}.870 \\
(.016)\end{array}$ & $\begin{array}{l}.531 \\
(.013)\end{array}$ & $\begin{array}{l}.485 \\
(.009)\end{array}$ & $\begin{array}{l}.788 \\
(.024)\end{array}$ & $\begin{array}{c}.636 \\
(.010)\end{array}$ & $\begin{array}{l}.539 \\
(.009)\end{array}$ & $\begin{array}{l}.786 \\
(.013)\end{array}$ & $\begin{array}{l}.654 \\
(.006)\end{array}$ & $\begin{array}{l}.506 \\
(.005) \\
\end{array}$ \\
\hline $\begin{array}{l}\text { Some post- } \\
\text { secondary }\end{array}$ & $\begin{array}{l}.077 \\
(.013)\end{array}$ & $\begin{array}{l}.352 \\
(.013)\end{array}$ & $\begin{array}{l}.375 \\
(.009)\end{array}$ & $\begin{array}{l}.138 \\
(.020)\end{array}$ & $\begin{array}{l}.191 \\
(.008)\end{array}$ & $\begin{array}{c}.273 \\
(.008)\end{array}$ & $\begin{array}{l}.139 \\
(.011)\end{array}$ & $\begin{array}{l}.185 \\
(.005)\end{array}$ & $\begin{array}{l}.279 \\
(.004)\end{array}$ \\
\hline Four-year degree & $\begin{array}{l}.053 \\
(.011)\end{array}$ & $\begin{array}{l}.117 \\
(.009)\end{array}$ & $\begin{array}{l}.140 \\
(.006)\end{array}$ & $\begin{array}{l}.074 \\
(.015)\end{array}$ & $\begin{array}{l}.173 \\
(.008)\end{array}$ & $\begin{array}{l}.187 \\
(.007)\end{array}$ & $\begin{array}{l}.076 \\
(.008)\end{array}$ & $\begin{array}{l}.161 \\
(.004)\end{array}$ & $\begin{array}{l}.215 \\
(.004) \\
\end{array}$ \\
\hline $\begin{array}{l}\text { Part-time (under } \\
30 \text { hours/week) }\end{array}$ & $\begin{array}{l}.226 \\
(.021)\end{array}$ & $\begin{array}{l}.276 \\
(.012)\end{array}$ & $\begin{array}{l}.233 \\
(.007)\end{array}$ & $\begin{array}{l}.200 \\
(.023)\end{array}$ & $\begin{array}{l}.185 \\
(.008) \\
\end{array}$ & $\begin{array}{l}.172 \\
(.007)\end{array}$ & $\begin{array}{l}.173 \\
(.012)\end{array}$ & $\begin{array}{l}.184 \\
(.005)\end{array}$ & $\begin{array}{l}.175 \\
(.004) \\
\end{array}$ \\
\hline Sample size & 416 & 1384 & 3147 & 297 & 2210 & 3229 & 1031 & 7018 & 10098 \\
\hline
\end{tabular}

NOTES: Standard errors are in parentheses. The sample is restricted to individuals of age 25 to 59 , with at least one week of work in the calendar year preceding the Census. 
Table 7

Estimated Coefficients from McFadden choice model among weeks-worked categories: Using Northern Maine counties only

\begin{tabular}{|c|c|c|c|c|}
\hline \multirow[t]{2}{*}{ Variable } & \multicolumn{2}{|c|}{ Men } & \multicolumn{2}{|c|}{ Women } \\
\hline & (1) & (2) & (3) & (4) \\
\hline Relative income & $\begin{array}{l}5.791 \\
(9.08)\end{array}$ & $\begin{array}{l}1.775 \\
(2.78)\end{array}$ & $\begin{array}{l}2.155 \\
(6.32)\end{array}$ & $\begin{array}{l}1.424 \\
(4.10)\end{array}$ \\
\hline $\begin{array}{l}\text { New Brunswick * } \\
1-13 \text { weeks }\end{array}$ & $\begin{array}{l}-1.632 \\
(5.50)\end{array}$ & $\begin{array}{c}.146 \\
(0.50)\end{array}$ & $\begin{array}{l}-.683 \\
(4.05)\end{array}$ & $\begin{array}{l}-.469 \\
(2.74)\end{array}$ \\
\hline $\begin{array}{l}\text { New Brunswick* } \\
14-26 \text { weeks }\end{array}$ & $\begin{array}{l}-.458 \\
(2.24)\end{array}$ & $\begin{array}{c}.830 \\
(3.94)\end{array}$ & $\begin{array}{l}-.079 \\
(0.59)\end{array}$ & $\begin{array}{c}.102 \\
(0.75)\end{array}$ \\
\hline $\begin{array}{l}\text { New Brunswick * } \\
27-39 \text { weeks }\end{array}$ & $\begin{array}{c}.349 \\
(5.14)\end{array}$ & $\begin{array}{c}.384 \\
(5.50)\end{array}$ & $\begin{array}{l}-.233 \\
(3.65)\end{array}$ & $\begin{array}{l}-.256 \\
(3.93)\end{array}$ \\
\hline $1980 * 1-13$ weeks & $\begin{array}{l}-.498 \\
(1.92)\end{array}$ & $\begin{array}{c}.326 \\
(0.97)\end{array}$ & $\begin{array}{l}-.621 \\
(3.99)\end{array}$ & $\begin{array}{l}-.427 \\
(2.50)\end{array}$ \\
\hline $\begin{array}{l}1980 * 14-26 \\
\text { weeks }\end{array}$ & $\begin{array}{l}-.637 \\
(4.07)\end{array}$ & $\begin{array}{l}.102 \\
(0.59)\end{array}$ & $\begin{array}{l}-.365 \\
(2.85)\end{array}$ & $\begin{array}{l}-.232 \\
(1.76)\end{array}$ \\
\hline $\begin{array}{l}1980 * 27-39 \\
\text { weeks }\end{array}$ & $\begin{array}{l}-.096 \\
(0.79)\end{array}$ & $\begin{array}{c}.052 \\
(0.42)\end{array}$ & $\begin{array}{l}-.262 \\
(2.16)\end{array}$ & $\begin{array}{l}-.284 \\
(2.30)\end{array}$ \\
\hline $1990 * 1-13$ weeks & $\begin{array}{l}-.584 \\
(2.25)\end{array}$ & $\begin{array}{c}.368 \\
(1.07)\end{array}$ & $\begin{array}{l}-1.311 \\
(8.26)\end{array}$ & $\begin{array}{l}-1.049 \\
(6.00)\end{array}$ \\
\hline $\begin{array}{l}1990 * 14-26 \\
\text { weeks }\end{array}$ & $\begin{array}{l}-.524 \\
(3.24)\end{array}$ & $\begin{array}{c}.356 \\
(2.00)\end{array}$ & $\begin{array}{l}-.556 \\
(4.44)\end{array}$ & $\begin{array}{l}-.366 \\
(2.83)\end{array}$ \\
\hline $\begin{array}{l}1990 * 27-39 \\
\text { weeks }\end{array}$ & $\begin{array}{l}-.293 \\
(2.46)\end{array}$ & $\begin{array}{l}-.089 \\
(0.73)\end{array}$ & $\begin{array}{l}-.662 \\
(5.62)\end{array}$ & $\begin{array}{l}-.667 \\
(5.52)\end{array}$ \\
\hline $\begin{array}{l}\text { Socio-economic } \\
\text { controls }\end{array}$ & No & Yes & No & Yes \\
\hline Pseudo $R^{2}$ & .539 & .560 & .285 & .313 \\
\hline$\chi^{2}$ & 20634.5 & 21422.5 & 8450.9 & 9249.9 \\
\hline
\end{tabular}

NOTES: t-statistics are in parentheses (in absolute value). The dependent variable equals one for the weeks worked category realized, zero for each other weeks worked category. Estimation is by conditional logit. The number of individuals in the sample is 13819 for men and 10683 for women. The 'relative income' variable is defined as the log of (part-year income / full-year income). In all cases, we use the predicted values of relative income, where the predictors include the following variables in addition to the regressors in the table: New Brunswick interacted with 1980, New Brunswick interacted with 1990, all the industry dummies interacted with New Brunswick, all the industry dummies interacted with New Brunswick and a post-1970 dummy, and education interacted with New Brunswick and a post-1970 dummy. Manufacturing is the omitted industry group, high school diploma or less is the omitted education group, and 1970 is the omitted year. The sample is restricted to individuals of age 25 to 59 . All equations include a full set of industry dummies. Standard errors are corrected for clustering on (year * region * industry * education) cells. 
Table 8

Actual versus Predicted Weeks-Worked Distributions, Conditional Logit Model

\section{a. Men}

\begin{tabular}{|c|c|c|c|c|}
\hline & \multicolumn{2}{|c|}{ New Brunswick } & \multicolumn{2}{|c|}{ Northern Maine } \\
\hline & Actual & Predicted & Actual & Predicted \\
\hline \multicolumn{5}{|l|}{ 1970: } \\
\hline $1-13$ weeks & 1.7 & 1.3 & 1.1 & 1.7 \\
\hline 14-26 weeks & 10.0 & 9.3 & 2.2 & 3.6 \\
\hline 27-39 weeks & 10.0 & 8.6 & 5.1 & 6.5 \\
\hline 40-52 weeks & 78.4 & 80.8 & 91.5 & 88.2 \\
\hline \multicolumn{5}{|l|}{ 1980: } \\
\hline $1-13$ weeks & 4.5 & 4.5 & 2.0 & 2.2 \\
\hline 14-26 weeks & 11.2 & 12.5 & 3.8 & 3.8 \\
\hline $27-39$ weeks & 8.2 & 8.9 & 6.7 & 7.2 \\
\hline $40-52$ weeks & 76.1 & 74.1 & 87.6 & 86.9 \\
\hline \multicolumn{5}{|l|}{ 1990: } \\
\hline 1-13 weeks & 4.5 & 4.5 & 2.2 & 2.5 \\
\hline 14-26 weeks & 16.3 & 15.6 & 3.9 & 5.0 \\
\hline 27-39 weeks & 7.6 & 7.5 & 5.5 & 6.5 \\
\hline $40-52$ weeks & 71.7 & 72.4 & 88.4 & 86.0 \\
\hline
\end{tabular}

\section{b. Women}

\begin{tabular}{|l|c|c|c|c|}
\hline & \multicolumn{2}{|c|}{ New Brunswick } & \multicolumn{2}{c|}{ Northern Maine } \\
\hline & Actual & Predicted & Actual & Predicted \\
\hline 1970: & & & & 11.6 \\
\hline $1-13$ weeks & 10.1 & 8.8 & 11.4 & 12.3 \\
\hline $14-26$ weeks & 16.6 & 18.0 & 13.6 & 14.8 \\
\hline $27-39$ weeks & 11.5 & 14.1 & 63.3 & 60.5 \\
\hline $40-52$ weeks & 61.8 & 59.1 & & \\
\hline & & & & 8.5 \\
\hline 1980: & & & 13.4 & 10.8 \\
\hline $1-13$ weeks & 14.7 & 13.6 & 12.8 & 12.8 \\
\hline $14-26$ weeks & 16.2 & 18.0 & 68.8 & 67.9 \\
\hline $27-39$ weeks & 11.3 & 11.3 & & \\
\hline $40-52$ weeks & 57.8 & 57.1 & & 6.8 \\
\hline & & & 7.8 & 10.1 \\
\hline 1990: & & & 9.7 & 74.2 \\
\hline $1-13$ weeks & 7.5 & 17.7 & 76.4 & \\
\hline $14-26$ weeks & 18.7 & 6.8 & & \\
\hline $27-39$ weeks & 9.1 & 64.4 & & \\
\hline $40-52$ weeks & 64.7 & &
\end{tabular}


Table 9

Predicted Effects of Hypothetical Changes to New Brunswick's UI System: Simulation with 1971 UI Act Removed

\begin{tabular}{|c|c|c|c|c|}
\hline & \multicolumn{2}{|c|}{ Men } & \multicolumn{2}{|c|}{ Women } \\
\hline & NB Baseline & $\begin{array}{c}\text { Without the } 1971 \\
\text { UI Act }\end{array}$ & NB Baseline & $\begin{array}{c}\text { Without the } 1971 \\
\text { UI Act }\end{array}$ \\
\hline \multicolumn{5}{|l|}{ 1970: } \\
\hline $1-13$ weeks & 1.3 & 1.3 & 8.8 & 8.8 \\
\hline 14-26 weeks & 9.3 & 9.3 & 18.0 & 18.0 \\
\hline 27-39 weeks & 8.6 & 8.6 & 14.1 & 14.1 \\
\hline 40-52 weeks & 80.8 & 80.8 & 59.1 & 59.1 \\
\hline \multicolumn{5}{|l|}{ 1980: } \\
\hline 1-13 weeks & 4.5 & 2.0 & 13.6 & 6.7 \\
\hline $14-26$ weeks & 12.5 & 8.7 & 18.0 & 14.2 \\
\hline 27-39 weeks & 8.9 & 8.1 & 11.3 & 11.8 \\
\hline $40-52$ weeks & 74.1 & 81.2 & 57.1 & 67.3 \\
\hline \multicolumn{5}{|l|}{ 1990: } \\
\hline $1-13$ weeks & 4.5 & 1.9 & 8.2 & 3.8 \\
\hline 14-26 weeks & 15.6 & 10.4 & 17.7 & 13.6 \\
\hline 27-39 weeks & 7.5 & 7.3 & 8.8 & 8.9 \\
\hline $40-52$ weeks & 72.4 & 80.4 & 65.4 & 73.7 \\
\hline
\end{tabular}

Table 10

Predicted Effects of Hypothetical Changes to New Brunswick's UI System: Simulation with Maine's UI Rules Imposed on New Brunswick

\begin{tabular}{|l|c|c|c|c|}
\hline & \multicolumn{2}{|c|}{ Men } & \multicolumn{2}{c|}{ Women } \\
\hline & NB Baseline & $\begin{array}{c}\text { With Maine's UI } \\
\text { system }\end{array}$ & NB Baseline & $\begin{array}{c}\text { With Maine's UI } \\
\text { system }\end{array}$ \\
\hline 1970: & & & & 6.0 \\
\hline $1-13$ weeks & 1.3 & 1.0 & 18.0 & 16.2 \\
\hline $14-26$ weeks & 9.3 & 8.0 & 14.1 & 15.8 \\
\hline $27-39$ weeks & 8.6 & 9.5 & 59.1 & \\
\hline $40-52$ weeks & 80.8 & 81.9 & & 3.8 \\
\hline & & & 13.6 & 13.8 \\
\hline 1980: & & & 18.0 & 13.9 \\
\hline $1-13$ weeks & 4.5 & 1.0 & 11.3 & 68.5 \\
\hline $14-26$ weeks & 12.5 & 10.2 & 57.1 & \\
\hline $27-39$ weeks & 8.9 & 80.1 & & 2.2 \\
\hline $40-52$ weeks & 74.1 & & 8.2 & 12.3 \\
\hline & & 1.0 & 8.8 & 75.4 \\
\hline 1990: & & 10.4 & 65.4 & \\
\hline $1-13$ weeks & 4.5 & 8.3 & & \\
\hline $14-26$ weeks & 15.6 & 80.3 & & \\
\hline $27-39$ weeks & 7.5 & & & \\
\hline $40-52$ weeks & 72.4 & & & \\
\hline
\end{tabular}


Table 11

Predicted Effects of Hypothetical Changes to New Brunswick's UI System: Simulation with Maine's UI Rules Imposed on New Brunswick, Less-educated sample

\begin{tabular}{|c|c|c|c|c|c|c|}
\hline & \multicolumn{3}{|c|}{ Men } & \multicolumn{3}{|c|}{ Women } \\
\hline & $\begin{array}{c}\text { New } \\
\text { Brunswick } \\
\text { Baseline }\end{array}$ & $\begin{array}{c}\text { Northern } \\
\text { Maine } \\
\text { Baseline }\end{array}$ & $\begin{array}{l}\text { NB with } \\
\text { Maine's UI } \\
\text { system }\end{array}$ & $\begin{array}{c}\text { New } \\
\text { Brunswick } \\
\text { Baseline }\end{array}$ & $\begin{array}{c}\text { Northern } \\
\text { Maine } \\
\text { Baseline }\end{array}$ & $\begin{array}{l}\text { NB with } \\
\text { Maine's } \\
\text { UI system }\end{array}$ \\
\hline \multicolumn{7}{|l|}{ 1970: } \\
\hline 1-13 weeks & 1.3 & 1.9 & 1.0 & 9.1 & 18.0 & 6.2 \\
\hline 14-26 weeks & 9.7 & 4.1 & 8.0 & 18.4 & 13.5 & 16.5 \\
\hline 27-39 weeks & 8.5 & 7.0 & 9.5 & 13.4 & 15.7 & 15.0 \\
\hline $40-52$ weeks & 80.5 & 87.0 & 81.8 & 59.0 & 52.8 & 62.2 \\
\hline \multicolumn{7}{|l|}{ 1980: } \\
\hline 1-13 weeks & 5.6 & 2.6 & 1.0 & 16.0 & 13.5 & 4.7 \\
\hline 14-26 weeks & 16.1 & 4.7 & 8.9 & 21.0 & 12.3 & 16.3 \\
\hline 27-39 weeks & 9.6 & 7.7 & 10.1 & 10.2 & 14.1 & 13.4 \\
\hline $40-52$ weeks & 68.7 & 85.0 & 80.0 & 52.7 & 60.1 & 65.7 \\
\hline \multicolumn{7}{|l|}{ 1990: } \\
\hline 1-13 weeks & 5.5 & 3.2 & 1.0 & 10.5 & 8.5 & 2.9 \\
\hline 14-26 weeks & 20.2 & 7.1 & 10.4 & 21.2 & 11.9 & 15.3 \\
\hline 27-39 weeks & 8.0 & 7.7 & 8.4 & 8.0 & 10.8 & 9.7 \\
\hline $40-52$ weeks & 66.3 & 82.0 & 80.3 & 60.3 & 68.9 & 72.1 \\
\hline
\end{tabular}

Note: Sample is restricted to persons with a high school degree or less education. 
Figure 1: New Brunswick, Maine and Maine's Northern Counties

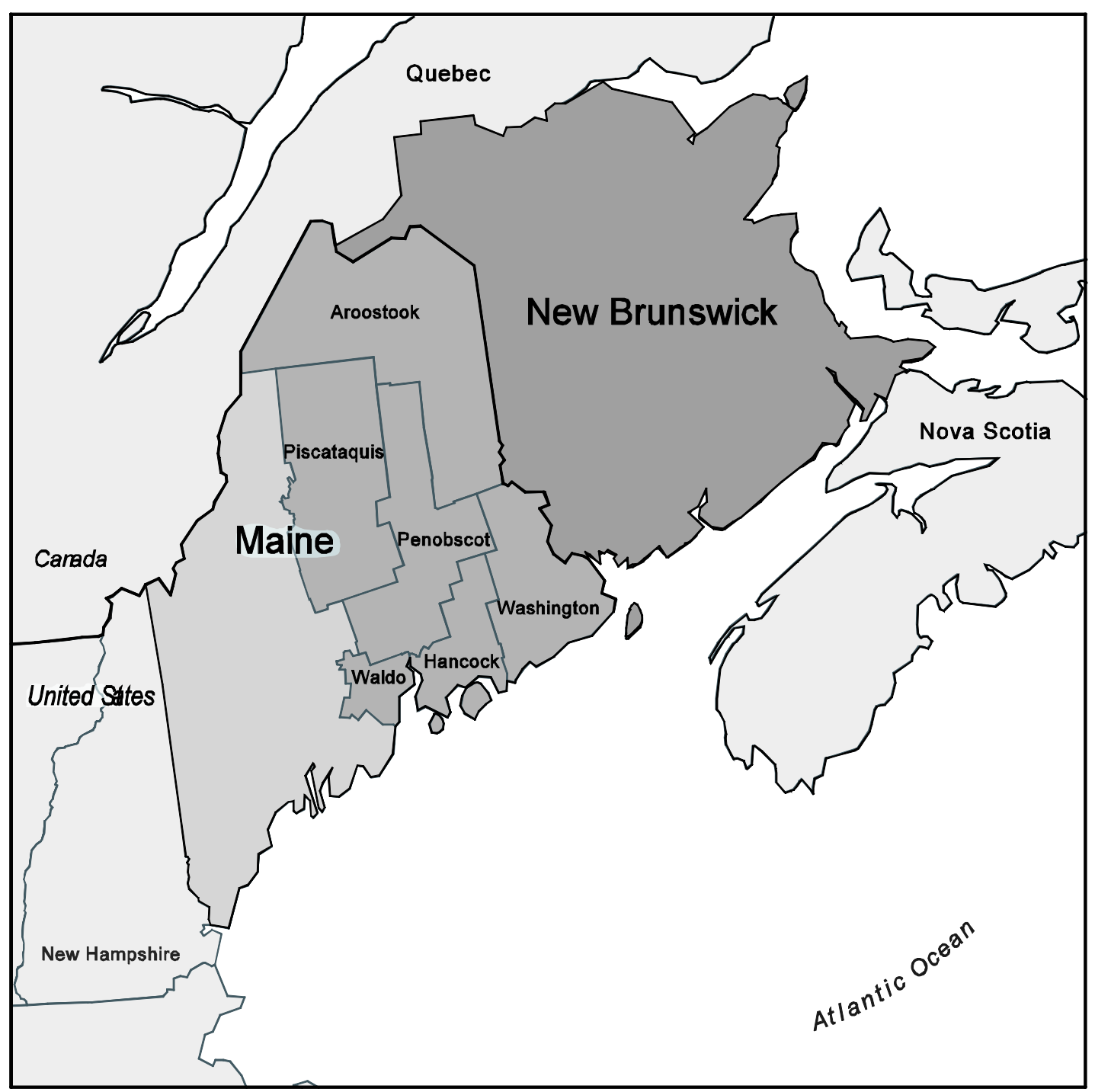


44

Figure 2: UI Expenditures in Maine and New Brunswick

a)

UI expenditures as a percentage of provincial/state GDP

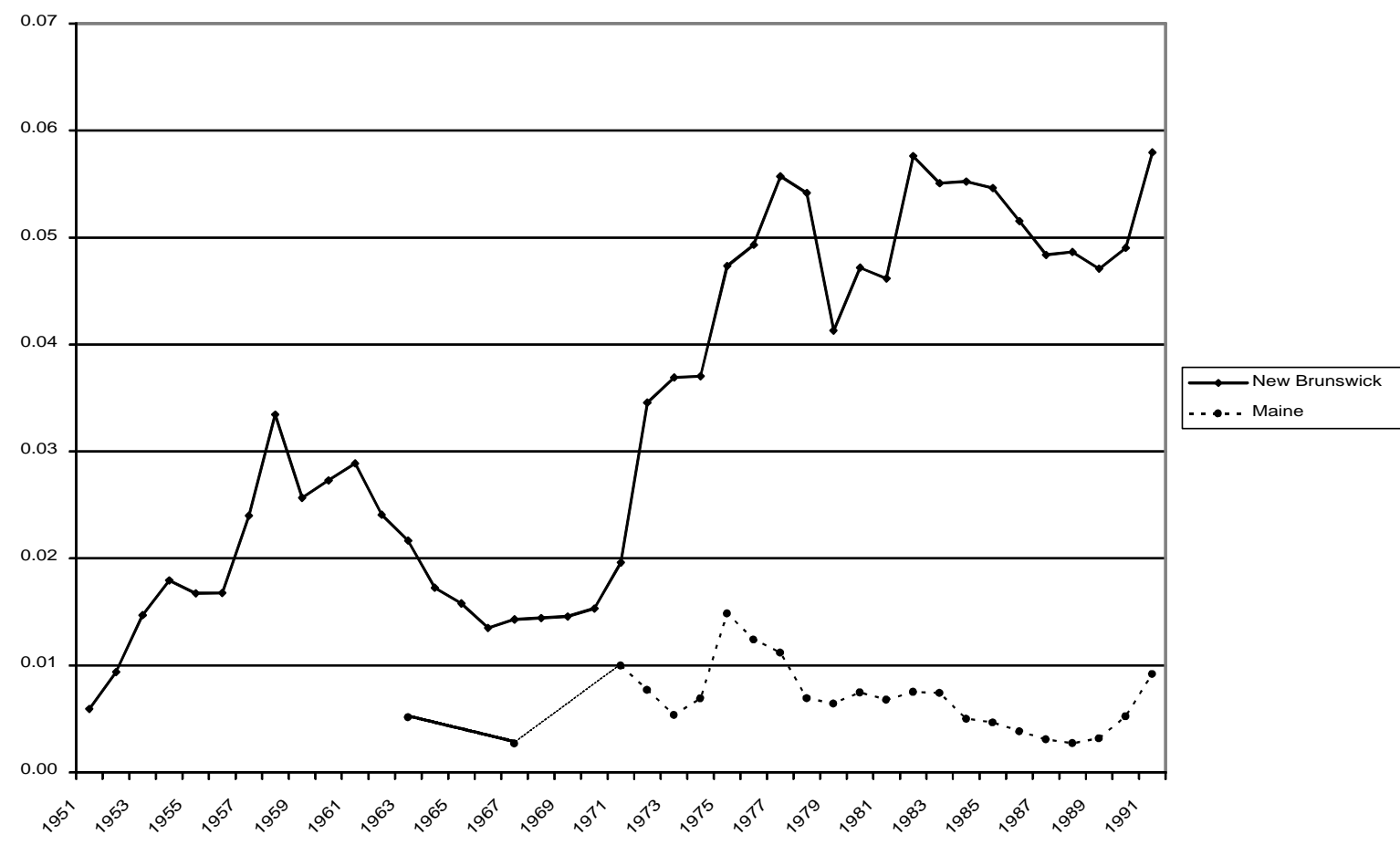


b)

UI expenditures as a fraction of total transfer payments to individuals

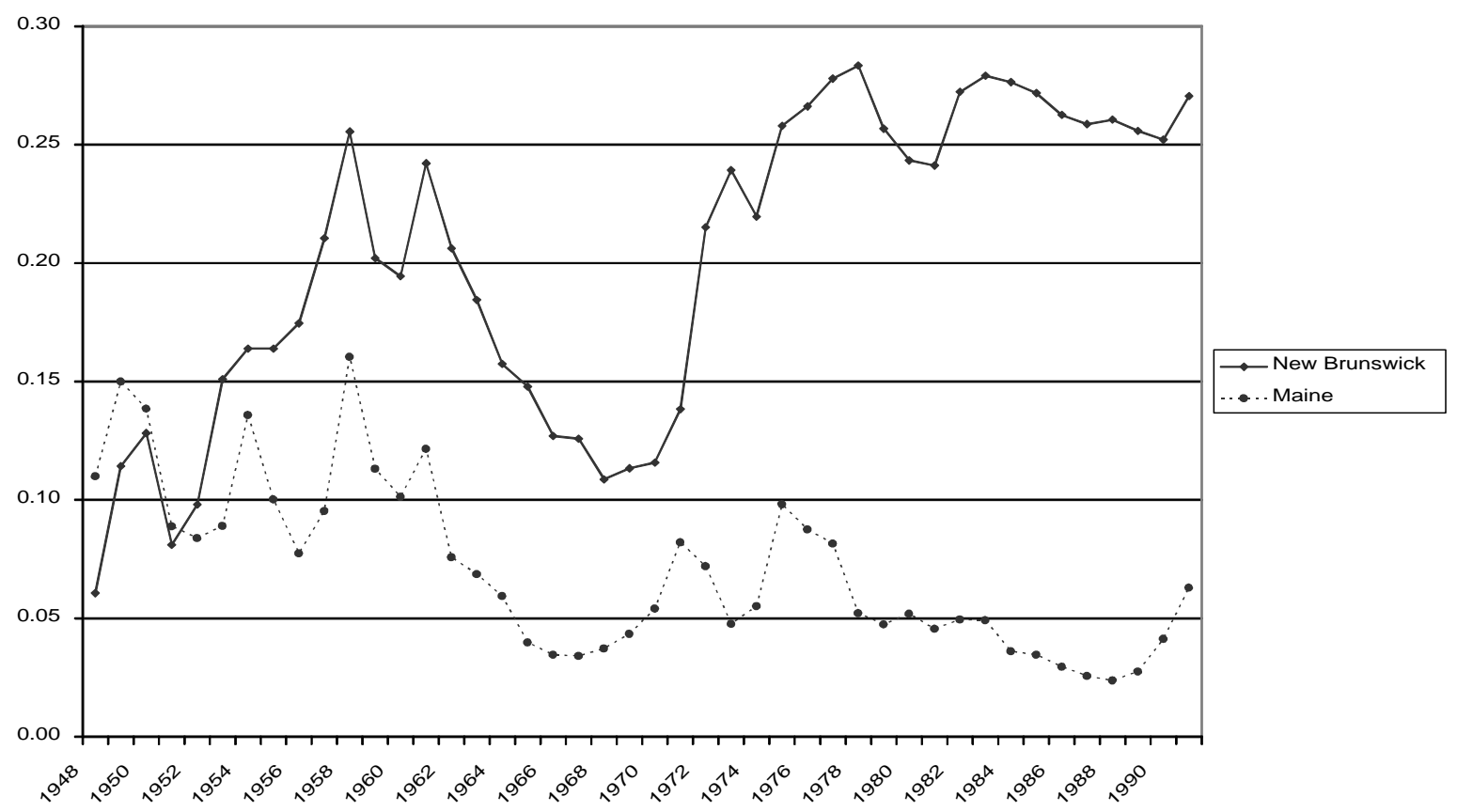

Notes:

In New Brunswick, “Total transfer payments to individuals" consist of: family and youth allowances; veterans' allowances, unemployment insurance benefits; scholarships and research grants; old age security; pensions to government employees (federal and provincial); adult education and training payments; provincial transfers such as direct relief, workers compensations, disability-related payments and grants to post-secondary institutions; CPP/QPP and miscellaneous federal/provincial/municipal transfer payments. For Maine, it consists of: all forms of retirement \& disability insurance benefit payments; worker's compensation payments; medical payments; income maintenance benefit payments; all UI-related benefit payments; all veteran-related payments; federal education and training payments; and miscellaneous federal/state/local transfers payments. For consistency between the jurisdictions, we include federal UI payments to individuals in Maine, which includes (depending on the year) payments for federal civilian government employees (after they became covered), railroad employees, and 'other' federal UI payments. These federal payments are a small fraction (about 10\%) of state payments.

Sources:

UI expenditures and total transfer payments for New Brunswick are from the National Income and Expenditure Accounts (and can be obtained through CANSIM, table number 3800047). GDP for New Brunswick was obtained from the Historical Statistics of New Brunswick (Ottawa: Statistics Canada, 1984). UI expenditures and total transfer payments for Maine are from the Regional Economic Accounts and were obtained from the Bureau of Economic Analysis. 
Figure 3: Unemployment Trends in Maine and New Brunswick

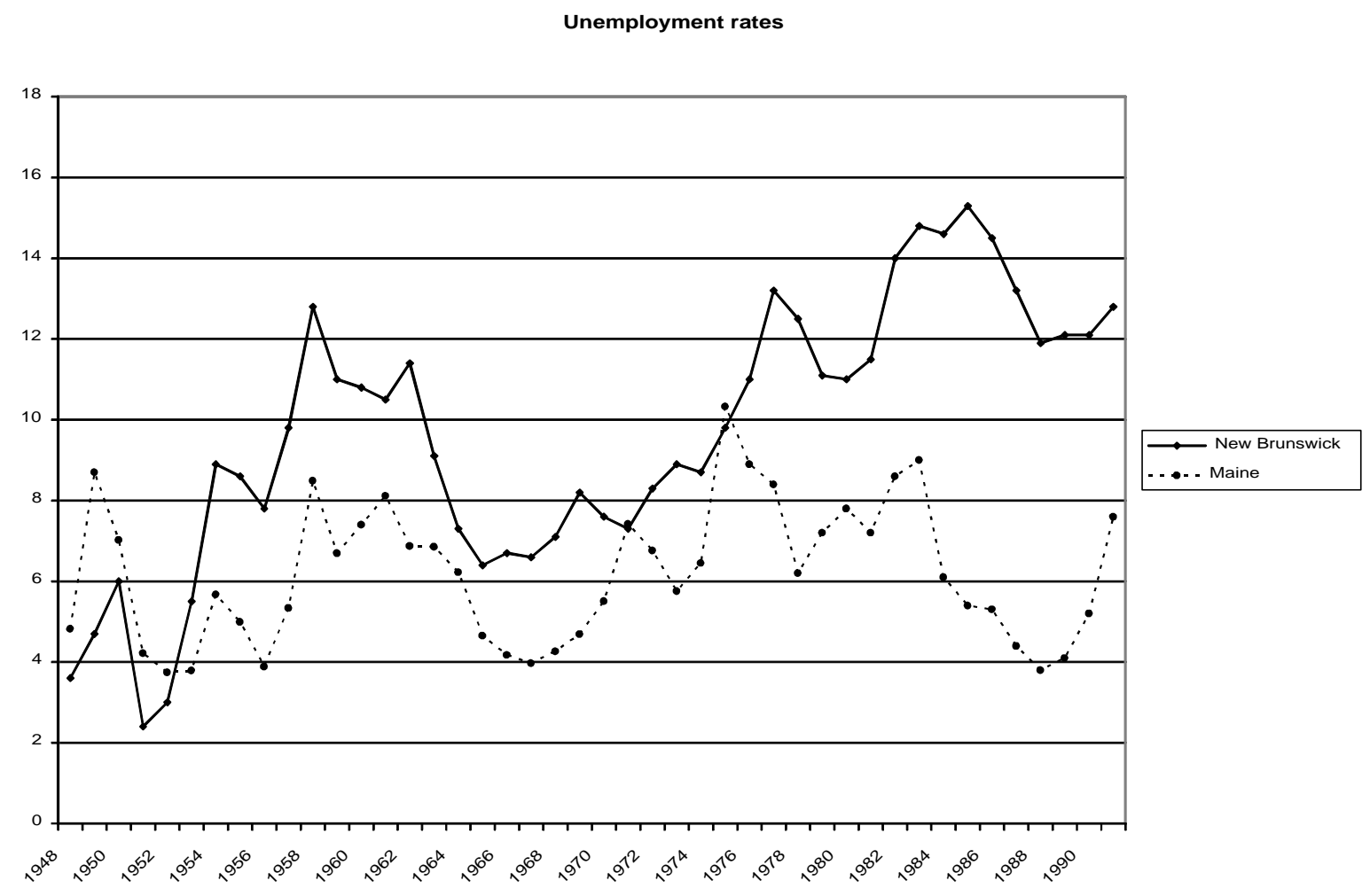

Sources: Historical Statistics of New Brunswick (Ottawa: Statistics Canada, 1984), and U.S. Bureau of Economic Analysis. 
Figure 4: Budget Constraints in the Two-Outcome Model

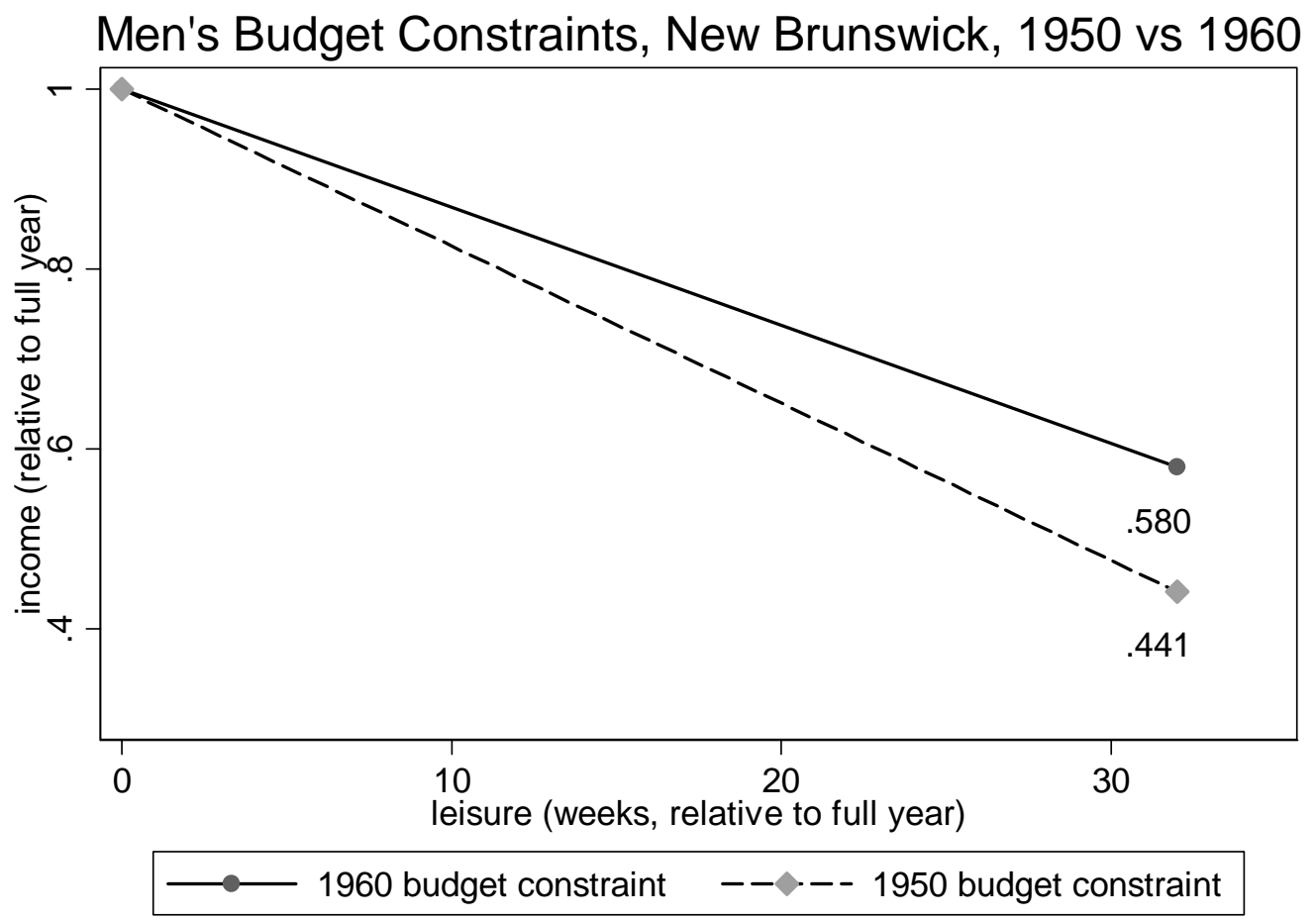

Figure 5: Budget Constraints in the Four-Outcome Model

Women's Budget Constraints, New Brunswick, 1970 vs 1980

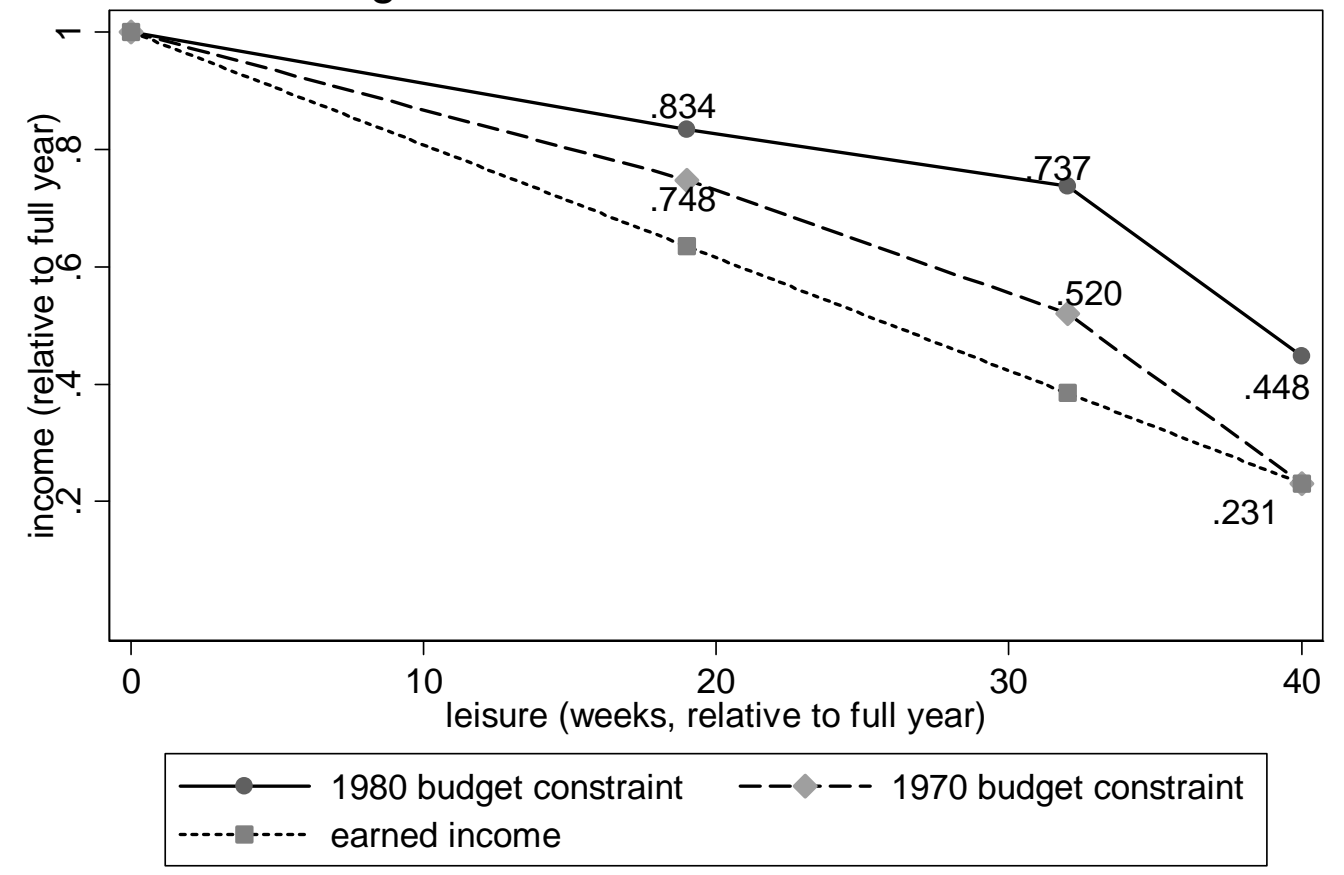




\section{Appendix 1: UI policy in Maine and New Brunswick, 1939-1991}

\section{A. Maine}

In 1939, 1949 and 1959, Maine's base period for the computation of UI benefits was the calendar year preceding the date of the claim. If eligible, a worker was entitled to 16 weeks of benefits in 1939 , 20 weeks in 1949 and 26 weeks in 1959 . Eligible workers' weekly benefit amount ( $w b a)$ was related to base period earnings via a fixed schedule (expressed in nominal dollars). 41 The original federal Act excluded from coverage workers in small firms, as well as agricultural and government workers.42 In 1954, federal civilian employees became included in the UI system under a separate program created especially for them. Self-employed workers have never been covered under Maine's UI system.

Maine's UI program underwent some further changes between 1959 and 1969. By 1969, the base period was defined as the first four of the previous five calendar quarters immediately prior to an application for benefits. Workers still needed to earn a minimum amount in the base period to be eligible for benefits, but now also needed positive earnings in at least two quarters of the base period. Total benefits were simply calculated as $1 / 3$ of base period earnings, within a minimum and maximum. The specific weekly benefit amount paid was determined by a fraction of high quarter earnings with benefit durations being determined residually (i.e., as total benefits $/ w b a$ ). The program parameters were such that benefit durations were restricted to a maximum of 26 weeks, with a minimum that ranged from 8 to 11 weeks depending on the year 43 A dependents' allowance also became available, provided that the claimant's spouse was not employed full-time. In addition, in 1969 and 1979 special restrictions applied to individuals working in firms that systematically employed their work force for 40 weeks or less; this was reduced to 26 weeks by 1989.44

Two other changes that are relevant to our analysis occurred in the U.S. unemployment insurance system between 1969 and 1979. First, coverage was extended to all employees of state and local governments 45 Also, agricultural employers with ten or more workers or a payroll of at least $\$ 20,000$ were required to pay UI taxes. Second, benefits for high income earners became subject to federal income taxation. 46 Apart from some changes in the benefit parameters and some other minor changes, the UI program in Maine has retained the above features to this day.

\footnotetext{
${ }^{41}$ Benefit schedules are posted at http://www.econ.ucsb.edu/ pjkuhn/Data/NBMaine/NBMaineIndex.html.

42 To be included, an employer needed to employ eight or more workers during at least 20 weeks of the year; this was reduced to four or more workers in 1954 and to one or more in 1970.

${ }^{43}$ Another change in UI in the United States was the implementation of federal-state extended benefits. This program extends benefits to worker during a defined period of high unemployment. Essentially, extended benefits are triggered if the insured unemployment rate equals or exceeds 120 percent of the average insured unemployment rate for the corresponding period in each of the two preceding calendar years (and must also be above $5 \%$ ). Extended benefits were not in effect during any of the relevant census years for Maine.

${ }^{44}$ Maine has had a long history of special seasonal regulations, which restrict benefits to unemployment that occurred during the seasonal operating period. For example, in 1989, an employee of a designated seasonal employer who worked 20 weeks would only be able to collect six weeks of benefits.

${ }^{45}$ In the estimates of UI benefits used in the cell data analysis, we assume that all government workers became covered in Maine between 1969 and 1979, and that agricultural workers remained uncovered during the entire period.

${ }^{46}$ In 1979 UI benefits in the U.S. became taxable at one-half the recipient's normal tax rate, for recipients who income exceeded $\$ 20,000$ (\$30,000 for married couples, assuming joint filing). For our analysis we incorporate
} 


\section{B. New Brunswick}

Canada's first Unemployment Insurance Act was passed in August 1940. According to Human Resources Development Canada's (2005) own history of UI, this made Canada "the last western industrialized nation to have unemployment insurance". Because Canada's system did not pay benefits until 1942, no UI system existed in New Brunswick in the first year of our data (1940) 47 By 1950, Canadian workers had to prove 180 contribution days within the preceding two years to qualify for regular UI benefits. Further, 60 of these days must have occured within the year (or 45 days within the 6 months) prior to the current claim.48 Weekly benefit amounts (which included a dependents' allowance), were a function of nominal weekly earnings; the maximum duration of benefits was one day of benefits for each five daily contributions made in the previous five years.49 This formula allowed a claimant with five years of continuous employment to get one year of benefits. A final key feature of New Brunswick's 1950 UI system was the so-called 'ratio rule', which reduced the maximum benefit duration by one day for each three days of benefits received in the previous three years. For seasonal workers, this imposed significant limits on benefit duration. Indeed the ratio rule was, to some extent, viewed in the early years of the plan as a way of ensuring that the seasonally unemployed would not draw out large amounts of benefit, thereby upsetting the actuarial basis of the plan. 0

In 1960, aside from being converted from a daily to a weekly basis, the qualifying requirement for regular UI in Canada was essentially unchanged from 1950: 30 weeks of work in the two years preceding the date of the claim, 12 of which must be in the past year. Between 1950 and 1960, however, significant changes occurred that dramatically expanded benefits available to persons with short work histories. In particular, the 1955 Unemployment Insurance Act introduced an explicit program of Seasonal Benefits.51. These benefits, payable only during the winter months, were available under quite broad conditions to workers unable to qualify for regular benefits, including those whose benefit rights had been exhausted. Workers attempting to qualify for a second regular or seasonal claim within two years, however, had also to satisfy a set of repeat user rules, leading to a very complex set of requirements, summarized in the final section of this Appendix. As we demonstrate quantitatively in the paper, the system of seasonal benefits available in 1960 constituted a significant enrichment of Canada's UI program for persons with short work histories, and marked a clear departure from the traditional insurance principles that had been its original foundation. Between 1960 and 1970, the main parameters of Canada's UI system remained virtually the same, though the real value of maximum weekly benefits was eroded somewhat by inflation.

taxes, for both regions, by assuming that the worker's only income is from wages and salary (i.e. due to data constraints, we ignore other income in the household).

${ }^{47}$ Interestingly, the 1940 Act specifically excluded a long list of detailed occupations and groups from UI coverage, including agriculture, forestry, fishing, logging, hunting, teachers, part-time workers, and most government workers. With the exception of agricultural and workers, these restrictions were eliminated by 1950, the first year in our data with an operational Canadian UI system.

${ }^{48}$ Beginning in 1951, workers who failed to meet these criteria were - under certain circumstances - eligible for a program of Supplementary Benefits. These benefits were paid only during the winter months, at 80 percent of a worker's regular weekly benefit amount. Since these benefits were not yet available in the winter of 1950, we do not include them in our measure of benefit generosity for that year.

${ }^{49}$ Benefit schedules are posted at http://www.econ.ucsb.edu/ pjkuhn/Data/NBMaine/NBMaineIndex.html

${ }^{50}$ For a review of many of the key aspects of Canada's UI system over the 1942 to 1980 period see Dingledine (1981).

${ }^{51}$ The Seasonal Benefits program replaced the Supplementary Benefits program that was in place from 1951 through 1954. Another interesting feature introduced in the $1950 \mathrm{~s}$ was a requirement for married women to demonstrate that they had not willingly left the labor market as a consequence of marriage, in order to qualify for UI. 
The second major enrichment of UI benefits pertaining to Canada's part-year workers during our sample period was contained in the 1971 Unemployment Insurance Act (Bill C-229), which came into effect in 1972. Benefit schedules that made the $w b a$ a function of the nominal weekly wage were abolished, as was the seasonal benefits system. By 1980, UI in Canada had taken on the following features. There were now three types of benefits available: regular benefits, labor force extended benefits and regional extended benefits. To qualify for regular benefits, workers were required to have worked 10 to 14 weeks, depending on the regional unemployment rate, in the last 52 weeks. Once eligible, each week worked qualified the worker for one week of regular benefits, up to a maximum of 25 weeks. Workers with longer attachment to the labor force were rewarded with one extra week of labor force extended benefits for each two additional weeks worked beyond the first 26 weeks. For harder hit areas, regional extended benefits offered an additional 2 weeks of benefits for every $.5 \%$ the regional rate exceeded $4 \%$, up to a maximum of 50 weeks. 52

The method of determining the $w b a$ had also changed. By 1980, the $w b a$ was calculated as (up to a maximum) $60 \%$ of average insurable earnings in the most recent 20 paid weeks prior to unemployment, and $67 \%$ for individuals with dependents. 53 Benefits were also, by this time, subject to taxation.54 In contrast to the 1950s, 1960s and early 1970s, the 1980s saw little change to Canada's UI program.

\section{Canada's Regular and Seasonal UI programs in 1960}

\section{i) Qualifying for UI:}

To qualify for regular benefits, claimants must have made at least 30 weekly contributions in the two years preceding the date of the claim; 8 of these must have occurred since the start of the last preceding regular benefit period or within the year preceding the claim, whichever is the shorter period; and 24 of these since the start of the last preceding benefit period, either regular or seasonal, or in the year preceding the claim, whichever is the longer period.

Workers who failed to qualify for regular benefits could qualify for Seasonal Benefits (payable only between from December 1 to mid-May) in two ways. "Class A" seasonal claimants must have failed regular benefit requirements, and have made 15 contributions since the Saturday preceding the $31^{\text {st }}$ of March immediately prior to the date of the claim. "Class B" claimants must have failed regular and seasonal class A requirements, and have had a regular benefit terminate since the Saturday following the $15^{\text {th }}$ of May immediately prior to the claim. Weekly Seasonal benefit amounts were equal to the regular benefit amount.

\footnotetext{
${ }^{52}$ As well, a new entrants/re-entrants rule was introduced in 1979, which established a 20 week entrance requirement for individuals who had less than 14 weeks worked in the 52 weeks prior to the start of their qualifying period. A repeater rule was also introduced in 1979. Coupled with the new entrants/re-entrants restriction, the repeater rule was an attempt to decrease the ease of entry for low attachment workers. However, since regions (such as New Brunswick) with an unemployment rate over $11.5 \%$ were exempted from the repeater rule, this rule does not enter into our analysis.

${ }_{54}^{53}$ All weeks were used if the period was less than 20 weeks.

${ }^{54}$ UI benefits first became taxable, as ordinary income, in 1972. As well, in 1979, recipients with annual net income greater than $\$ 20,670$ (1.5 times maximum insurable earnings) had to reimburse $30 \%$ of the benefits that made up the excess. For example, a person who received $\$ 3000$ in UI, and whose net income exceed the threshold $(\$ 20,670$ for the 1980 census year) by $\$ 3000$ had to repay $\$ 900(.3 * \$ 3000)$.
} 


\section{ii) Benefit Duration:}

A claimant was entitled to receive one week's regular benefit for every two contribution weeks in the two year period prior to the claim. However, if there was a regular or seasonal benefit period within this period of two years, only contribution weeks in the last year, or in the period since the start of the last benefit period, whichever was longer, could be used for computing benefit. The minimum duration of benefit is 12 weeks. The duration of Class A Seasonal Benefits was determined by either five benefit weeks for every 6 contribution weeks made since the last March $31^{\text {st }}$ or the number of possible benefit weeks from the claim to May 15, whichever is less. The duration of Class B Seasonal benefits was the number of weeks in the immediately previous regular benefit period, or the number of possible benefit weeks from the claim to May 15, whichever is less. The minimum duration for Class A benefits was 13 weeks; for Class B it was 12 weeks unless the number of possible weeks from the claim to May 15 was less than that.

\section{iii) Repeat-user rules:}

For persons classed as "repeat claimants", Section 45(2) of the 1955 UI Act restricted the degree to which contributions could be used a second time as qualifying credits. Section 45(2) of the Act applied to all persons for whom a previous benefit period (either regular or seasonal) was established within the two year period preceding the current claim. The operation of this Section is best illustrated by three examples:

Claimant I had no previous benefit period within the last two years. To qualify for regular benefit he was required to prove 30 contribution weeks in two years, of which eight must be shown in the year immediately preceding the claim.

Claimant II had a previous benefit period 18 months ago. He also must prove the 30 and 8 weeks requirement. However, 24 of the 30 contribution weeks must occur since the commencement date of that previous benefit period 18 months ago. In addition, only the 24 weeks count in calculating the duration formula, the remaining contribution weeks within the two years having been used to calculate the previous benefit rights may not be used a second time.

Claimant III had a previous benefit period 10 months ago. He must prove the 30 week requirement, but in this case, the 24 weeks must have been accumulated within the last year. The eight week test is automatic upon the fulfillment of the 24 week test.

Failures resulting from these tests during December to mid-May were considered for Seasonal benefit. The contribution record since the preceding March 31 was be examined first and if at least 15 contribution weeks were shown, a Class A Seasonal benefit period was established. Failing this, the benefit record was examined and if a regular benefit period was shown as terminated since the previous mid-May, then eligibility could be established under Class B.

If it is assumed that all three examples cited above were failures for regular benefit and that this occurred during the months when seasonal benefit was operative, the following adjudications were possible: Claimant I could qualify under class A provided he had at least 15 contribution weeks since the preceding March 31. He would not be eligible under class B. Claimants II and III would be tested first for the 15 contribution weeks since the preceding March 31 and failing that, they could qualify under class B provided the termination date of their previous benefit periods was subsequent to the preceding May 15. 


\section{Appendix 2: Data}

\section{A. Weeks Worked and Part-Year Work}

In all cases except Canada in 1941 and 1951, the weeks worked variables refer to annual weeks worked in the year prior to the census year, and are used to compute the part-year work variables. In 1941-51 Canadian censuses, weeks worked referred to the one year period prior to the June reference week (i.e., June 1940-June 1941 instead of January 1940 to December 1940). Prior to 1980, the U.S. census coverage was individuals14+, which changed to $16+$ in 1980; in the Canadian census, coverage changed from $14+$ to $15+$ in 1971 . In addition, prior to 1971 only wage-earners were asked their weeks worked in Canada (i.e., self-employed and unpaid family workers were excluded). In the cell-level analysis this variable is the proportion of individuals in the gender/industry/region/year cell that work less than 40 weeks.

Weeks worked are available as continuous variables only in the 1980/81 and 1990/91 U.S. and Canadian censuses. In previous years, in each country, weeks worked were categorized as follows: U.S. (all years) 1-13, 14-26, 27-39, 40-47, 48-49, 50-52; Canada (1961, 1971) 1-13, 14-26, 27-39, 40-48, 4952; Canada $(1941,1951) 1-19,20-29,30-39,40-49,50-52$. In the 1940 U.S. census and the 1941 and 1951 Canadian censuses, individuals who worked part-time had their weeks worked converted into fulltime equivalent weeks worked (i.e., an individual working 40 weeks at 20 hours per week would appear in the data as 20 weeks worked). We convert reported weeks worked into an estimated actual weeks worked for these three sets of cells using the hours worked information in the U.S. census. We rely on the assumption that the propensity to work part-time was the same in Canada as it is was in the U.S. Individuals in the 1940 U.S. census who worked 15-29 hours and had weeks worked of 14-26 or 27-39 were reallocated to full-year work. The net adjustments made to the 1940 numbers were then made by industry and gender to the New Brunswick numbers (the 1950 U.S. census is used for the $1950 \mathrm{New}$ Brunswick adjustments).

\section{B. Relative Income}

Computation of relative income begins with deriving weekly wages. For Maine, weekly wages are based entirely on census micro-data. For 1940, 1950, 1980 and 1990 the respondent's weekly wage is annual income from wages and salary divided by the number of weeks worked. For 1960 and 1970, a continuous weeks-worked variable was not available in the public use microdata files, and thus the weekly wage equals wage and salary income divided by the midpoint of the weeks worked category. The categories available in the 1960 and 1970 censuses (and midpoint value adopted) are 1-13 (6), 14-26 (20), 27-39 (33), 40-47 (43), 48-49 (49), and 50-52 (51). For New Brunswick, weekly wages are based on published census data for 1941-61, and census micro-data for 1971, 1981 and 1991 (a categorical weeks worked variable is available in the 1971 census - see section above - and a continuous weeks worked variable is available in both 1981 and 1991; weekly wages are calculated in the same manner as above for Maine). For 1951, weekly earnings itself was not available and so categorical earnings information (total of seven categories, we use the midpoints) are used to compute a weighted weekly earnings average.

For the cell-level analysis, relative income under the 20 weeks worked assumption is then calculated as: relative income $=[($ weekly wages $\{g, y, i, c\} * 20)+\mathrm{UI}\{y, c\}] /($ weekly wages $\{g, y, i, c\} * 52)$ where $g$ is gender, $y$ is census year, $i$ is industry and $c$ is country. UI is income from unemployment insurance, and equals the weekly benefit amount times benefit duration. UI for Maine is calculated based on the weekly wage (either the individual's or the cell value) and prevailing UI rules. Benefit durations in Maine are discussed in the text of the paper. For New Brunswick, UI is calculated based on the prevailing UI rules 
for a given weeks worked assumption (20 or 30 weeks) with the weekly benefit amount computed based on the schedules available in the on-line appendices, or as $60 \% / 67 \%$ (without/with dependents) for post1971 UI Act census years. In the cell-level analysis (where the presence of dependents is not observed), a 50 percent probability of having dependents is assigned when that affects benefits. For benefit durations for New Brunswick, see Appendix 1.

As Appendix 1 made very clear, weeks of UI eligibility in New Brunswick sometimes depend not just on the number of work weeks in the past year, but on weeks in earlier years as well. In those (relatively rare) cases, we compute eligibility under the assumption the worker has the same annual weeks-worked pattern every year. In addition, a person's UI eligibility sometimes depends not just on the number of weeks worked in a year, but on their precise distribution over time. Whenever the precise distribution matters, we calculate UI benefits for the distribution of weeks that maximizes a worker's UI benefits.

Also, as noted in the paper, our imputed benefit levels focus on an individual who works part-year every year. Under the 1955 UI Act, some "chronic" part-year workers would never qualify for regular benefits, but would qualify for seasonal benefits. To incorporate this policy feature, when regular benefits under the 1955 UI Act enter our analysis, we compute the average number of benefit weeks that the individual would receive over the $1942-X$ period (where $X$ is the census year in question) assuming they worked a certain number of weeks every year.

\section{Education}

For education, the Canadian censuses are the richer source and thus the U.S. variable is used as the base. In general, prior to 1990, the U.S. census tends to report years of education while the Canadian census has a combination of years of education and credential information. The only education variable available in the 1970 and 1980 U.S. censuses used in the micro-data analysis is the "highest grade of school' variable, which has the following categories: a category for each grade from kindergarten through grade 12 where grade 12 includes both individuals who graduated with a high school diploma and those who did not; and categories for each year of university completed (to a maximum of eight). The 1990 U.S. census changed the education question to a highest level of attainment (i.e., credential). As such, education in the 1990 census is not comparable to previous census years. IPUMS provides a recoded variable, which we use, where they place grade 12 (with and without high school diploma) in a single category, equate 1 to 3 years of college with all post-secondary categories under a Bachelor's, and then equate 4+ plus years of college with a Bachelor's or greater. In the Canadian census, we set grade 11 and under as "less than high school" and grade 12 as "high school", keeping in mind that this includes some individuals without a high school diploma. We set 1 through 3 years of post-secondary schooling as "some post-secondary" and 4+ years as "degree".

Creating education variables from the Canadian census that are as consistent as possible with the U.S. is done as follows. For 1971, we use grade 11 and under for "less than high school" and grade 12 plus grade 13 as "high school" (includes those with and without a high school diploma); university 1 to 2 years plus university 3 to 4 years, no degree as "some post-secondary"; university 3 to 4 years with degree, and university 5+ years (with and without degree categories) as "degree". For 1981 and 1991, we use two education variables -'highest level of school' and 'highest level of elementary and secondary' - in order to create a "high school" variable that includes both high school graduates and grade 12/13 non-graduates. "Some-post secondary" includes all non-university groups (trades certificates, etc.) as well as some university without a degree and university with certificate/diploma while "degree" includes any university graduate. The only difference in the 'highest level of schooling' variable between the 1981 and 1991 Canadian censuses is that university graduates are separated into BAs, masters and doctorates in the 1991 census. 


\section{Basic Demographics}

Age, gender, marital status and school enrollment are virtually all consistent across years within country and across country. Common-law couples are considered as married in both countries for the 1970 to 1990 census years. For our "children in household" variable, we use the "number of children in household' variable for the U.S. A 'number of children in household' variable does exist in the Canadian census, but was only asked of women (and only married or once married women prior to the 1991 census). Thus, for the 1981 and 1991 Canadian censuses we use household type, which indicates the presence of never married children in the household, and should yield a variable that is consistent with the U.S. variable. For 1971, we are forced to use a combination of marital status, size of census family, and - for women only - the children in household variable. For men, we define children as equaling one if family size is greater than two and the individual is married.

\section{E. Part-time work}

In the Canadian census, a question is asked, from 1981 through 1991, about whether the weeks worked in the previous year were full-time weeks or part-time weeks. In 1971 'usual hours worked' is available, which asks the individual their usual hours worked from the previous year and should be fairly comparable to the full-time/part-time weeks worked variables in 1981 and 1991. One issue, however, is that the part-time weeks worked question in 1981 did not specifically attach a number of hours to parttime status whereas the 1991 census attached a less than 30 hours per week value. For the U.S. census, 'usual hours worked' - based on the previous year - was first asked in 1980, while 'hours worked last week' (i.e., hours worked in the census reference week) is consistently available. We use usual hours worked for the 1980 and 1990 U.S. census, but are forced to use hours worked in the reference week for the 1970 U.S. census. Regardless of which hours variable is used, part-time work is defined as less than 30 hours per week in all cases.

\section{F. Industry}

We are forced to use the 1971-1991 Canadian census industry variables as the base. Some improvements were made to the industry variables in 1981 and 1991, but for consistency across time we must use the 1971 industry definition which was made available in all three Canadian micro-data censuses. In both countries, industry refers to the individual's main job (based on hours worked) and is only asked of those working since January 1 of the year previous to the census year (e.g., January 11980 in the case of the 1981 Canadian census data). In both countries, for individuals not working during the census reference week, industry refers to the job of longest duration. The 1971 industry variable has 12 categories available: agriculture, forestry, fishing, mining, manufacturing, construction, transportation/storage/communication/utilities, wholesale/retail trade, finance/insurance/real estate, community/business/personal/recreational services, and public administration in addition to a 'not specified' (or not classifiable) category. Given the merging of forestry/fishing/mining (the latter being negligible in both New Brunswick and Maine) we are left with eight categories for both the aggregate data and micro-data analyses. We drop the 'not specified' category.

For the U.S., we use the IPUMS 'Industry, 1950 basis' recode, which is a highly consistent across years. The only across-time inconsistency in this variable was following the 1970 census where coverage was changed from individuals $14+$ who had worked in the previous ten years to individuals $16+$ who had worked in the previous five years. A total of 148 categories are available. For Canada, the 1970 industry classification is highly comparable to the industries in the 1960 census.55 The key inconsistencies arise

\footnotetext{
${ }^{55}$ Given our focus on part-year work, it is worth noting that it is unclear how teachers' summers have been treated over time. For instance, in the U.S. census in 1940, school teachers were not to count their summer vacations as time worked, but in 1950 teachers were to report all weeks paid (including paid absences, vacations, and sick time).
} 
when comparing the U.S. 1950 industry codes with the 1971 Canadian industry codes. Given the rich nature of the U.S. data we are able to create reasonably comparable industries across countries after recoding 'logging' from manufacturing (in the U.S.) into primary (for Canada). With public-use data, however, there are some inconsistencies that cannot be corrected for. Our reading of the U.S. 1951 classification (see U.S. Bureau of Census, Alphabetic Index of Occupations and Industries: 1950, Washington, D.C., 1950) relative to the Canadian 1971 classification is that most inconsistencies come from specialized services specific to an industry. For instance, the U.S. places oil and gas field services in mining while Canada places it in professional services. On the other hand, Canada places research and testing services incidental to agriculture in agriculture while the U.S. places them in professional services. Various examples go both ways, but they are largely limited to highly specialized services, which are unlikely to amount to substantive inconsistencies overall. Manufacturing, trade, finance etc., and the primary sector (after re-coding logging) are highly consistent across the two countries.

\section{G. Wage and salary income}

Our measures of wage income are highly consistent, both over time and between countries. The level at which these variables are top-coded however does vary however. In both countries, wage income refers to gross wages and salaries, before deductions (for items such as income tax, pensions, union dues, unemployment insurance), for the previous calendar year (i.e., the year to which the weeks worked variables refer). Payments-in-kind or reimbursements for business expenses are excluded in both countries. Commissions, tips, bonuses, piece-rate payments, and military pay are included in both countries (military bonuses were excluded in the U.S. for 1950 - 1970 censuses).

In later years, there were no specific instructions, and it would seem that teachers who received pay over the summer would have considered this to be paid vacation and therefore would have included it as weeks worked. 